\title{
Glutamate Transporter-Mediated Glutamate Secretion in the Mammalian Pineal Gland
}

\author{
Mean-Hwan Kim, ${ }^{1}$ Shunsuke Uehara, ${ }^{2}$ Akiko Muroyama, ${ }^{2}$ Bertil Hille, ${ }^{3}$ Yoshinori Moriyama, ${ }^{2}$ and Duk-Su Koh ${ }^{1,3}$ \\ ${ }^{1}$ Department of Physics, Pohang University of Science and Technology, Kyungbuk 790-784, Republic of Korea, ${ }^{2}$ Department of Biochemistry, Faculty of \\ Pharmaceutical Sciences, Okayama University, Okayama 700-8530, Japan, and ${ }^{3}$ Department of Physiology and Biophysics, University of Washington, \\ Seattle, Washington 98195-7290
}

\begin{abstract}
Glutamate transporters are expressed throughout the CNS where their major role is to clear released glutamate from presynaptic terminals. Here, we report a novel function of the transporter in rat pinealocytes. This electrogenic transporter conducted inward current in response to L-glutamate and $\mathrm{L}$ - or $\mathrm{D}$-aspartate and depolarized the membrane in patch-clamp experiments. $\mathrm{Ca}^{2+}$ imaging demonstrated that the transporter-mediated depolarization induced a significant $\mathrm{Ca}^{2+}$ influx through voltage-gated $\mathrm{Ca}^{2+}$ channels. The $\mathrm{Ca}^{2+}$ rise finally evoked glutamate exocytosis as detected by carbon-fiber amperometry and by HPLC. In pineal slices with densely packed pinealocytes, glutamate released from the cells effectively activated glutamate transporters in neighboring cells. The $\mathrm{Ca}^{2+}$ signal generated by $\mathrm{KCl}$ depolarization or acetylcholine propagated through several cell layers by virtue of the regenerative "glutamate-induced glutamate release." Therefore, we suggest that glutamate transporters mediate synchronized elevation of L-glutamate and thereby efficiently downregulate melatonin secretion via previously identified inhibitory metabotropic glutamate receptors in the pineal gland.
\end{abstract}

Key words: glutamate transporters; depolarization; calcium; secretion; patch clamp; pineal

\section{Introduction}

Excitatory amino acid transporters (EAATs) sequester the excitatory amino acids (EAAs) glutamate and aspartate from synaptic clefts in the mammalian CNS (Danbolt, 2001; Tzingounis and Wadiche, 2007). Their major function is to terminate glutamatergic signal transmission preparing postsynaptic glutamate receptors for the next transmission from the presynaptic terminal. Rapid removal of extracellular glutamate is also important for reducing toxic effects of the neurotransmitter (Weiss et al., 1990; Rothstein et al., 1996). So far, five different $\mathrm{Na}^{+}$-dependent glutamate transporters have been cloned: GLAST (glutamate-aspartate transporter) (homolog of EAAT1 cloned in human) (Storck et al., 1992), GLT-1 (EAAT2) (Pines et al., 1992), EAAC1 (EAAT3) (Kanai and Hediger, 1992), EAAT4 (Fairman et al., 1995), and EAAT5 (Arriza et al., 1997). Each subtype is expressed in different cell types and brain regions and facilitates glutamate uptake into neurons or glial cells.

The mammalian pineal gland is one of several brain regions containing high levels of L-glutamate and L- and D-aspartate (Schell et al., 1997). The synaptic-like microvesicles (SLMVs) of pineal cells contain L-glutamate and L-aspartate, which are se-

Received June 12, 2008; accepted Aug. 29, 2008.

This work was supported by grants from the Korean Ministry of Commerce, Industry and Energy (D.-S.K.), the Japanese Ministry of Education, Science, Sports and Culture (Y.M.), and National Institutes of Health Grant GM083913 (B.H.). M.-H.K. was supported by Korea Research Foundation Grant KRF-2006-612-C00011 and Brain Korea 21 to S. H. Kim (POSTECH). We thank J.-H. Cho, J. Myung, S. Han, H. Yamada, and M. Kinoshita for help with experiments and J. G. Duman for the comments on this manuscript.

Correspondence should be addressed to Dr. Duk-Su Koh, Department of Physiology and Biophysics, University of Washington, Box 357290, Health Sciences Building, Seattle, WA 98195-7290. E-mail: koh@u.washington.edu.

D0I:10.1523/JNEUROSCI.0894-08.2008

Copyright $\odot 2008$ Society for Neuroscience ～0270-6474/08/2810852-12\$15.00/0 creted through regulated exocytosis (Yatsushiro et al., 1997). $\mathrm{D}$-Aspartate is also abundant in the cytoplasm of pinealocytes and is gradually released through a pathway distinct from SLMVmediated exocytosis (Ishio et al., 1998). After release, the EAAs are resequestered through a GLT-1-type glutamate transporter (Yamada et al., 1997b; Yatsushiro et al., 1997). In addition to their role in glutamate clearance, glutamate transporters can contribute to the membrane potential because they are electrogenic. One stoichiometric uptake cycle transports three $\mathrm{Na}^{+}$, one $\mathrm{H}^{+}$, and one negatively charged glutamate into the cell and one $\mathrm{K}^{+}$out of the cell, resulting in the net influx of two positive charges (Zerangue and Kavanaugh, 1996; Levy et al., 1998; Owe et al., 2006). Therefore, forward operation of EAATs depolarizes the membrane, an effect most prominent with a negative resting potential, with a high density of the transporters, and with a high membrane input resistance. Furthermore, there is a nonstoichiometric conductance for small anions ( such as $\mathrm{Cl}^{-}$) associated with active EAATs that would serve as an additional influence on the membrane potential. Therefore, we addressed whether glutamate transporter currents contribute to the excitability of pinealocytes. Our biophysical and biochemical measurements demonstrate that pineal glutamate transporters can depolarize the membrane enough to activate voltage-gated $\mathrm{Ca}^{2+}$ channels, increase intracellular $\mathrm{Ca}^{2+}$ concentration $\left(\left[\mathrm{Ca}^{2+}\right]_{\mathrm{i}}\right)$, and finally induce $\mathrm{Ca}^{2+}$ dependent exocytosis of L-glutamate. We discuss the potential role of this transporter-mediated signaling in terms of melatonin production in the pineal gland based on the fact that aspartate and glutamate inhibit melatonin synthesis (Yamada et al., 1997a; Ishio et al., 1998). 


\section{Materials and Methods}

Cell culture. Dissociated pinealocytes were prepared from male Sprague Dawley rats (4-6 weeks old) as described previously (Yamada et al., 1996a). Briefly, pineal glands were removed from rats killed with $\mathrm{CO}_{2}$, according to University of Washington and Okayama University animal guidelines. The glands were dissected into small pieces in cold HBSS (Invitrogen) containing $5 \mathrm{~mm}$ D-glucose, $20 \mathrm{~mm}$ HEPES, and $1 \mathrm{mg} / \mathrm{ml}$ BSA, and treated with $4 \mathrm{mg} / \mathrm{ml}$ collagenase (Sigma-Aldrich) in HBSS solution at $37^{\circ} \mathrm{C}$ for $30-40 \mathrm{~min}$. Cell clusters were dispersed by trituration in a $\mathrm{Ca}^{2+}$-free HBSS containing 1 mM EGTA, 20 mM HEPES, and 10 $\mathrm{mg} / \mathrm{ml} \mathrm{BSA}$. Isolated cells were plated on glass coverslips and kept at $37^{\circ} \mathrm{C}$ in a 5\% $\mathrm{CO}_{2}$ incubator for 1-2 $\mathrm{d}$ in RPMI 1640 culture medium (Invitrogen) containing $10 \mathrm{~mm}$ glucose, $10 \%$ FBS, $100 \mu \mathrm{g} / \mathrm{ml}$ streptomycin, and $100 \mathrm{IU} / \mathrm{ml}$ penicillin before use. For single-cell experiments, pinealocytes were visually identified using differential interference contrast (DIC) optics (see Results).

Preparation and measurement of pineal slices. A dissected pineal gland was dropped into warmed $\left(39^{\circ} \mathrm{C}\right)$ HBSS containing $2 \%$ liquefied agar (Difco), sucked into the end of a glass Pasteur pipette (inner diameter, 5.5 $\mathrm{mm}$; VWR Scientific), and cooled rapidly in cold HBSS. The solid agar block containing the gland was sliced using a tissue vibratome (series 1000; Vibratome) in cold HBSS bubbled with $95 \% \mathrm{O}_{2}$ and $5 \% \mathrm{CO}_{2}$ (Takahashi, 1978). Slices were incubated for at least $30 \mathrm{~min}$ at room temperature with gas bubbling and used for experiments during the next $5 \mathrm{~h}$. Pinealocytes in the pineal slices were visualized using infrared DIC video microscopy using a Pixelfly CCD camera (Applied Scientific) on an Eclipse 80i upright microscope (Nikon).

Solutions and drugs. The standard extracellular saline solution for single-cell measurements contained the following (in mM): $137.5 \mathrm{NaCl}$, $2.5 \mathrm{KCl}, 2 \mathrm{CaCl}_{2}, 1 \mathrm{MgCl}_{2}, 10$ D-glucose, and 10 HEPES, pH 7.3 adjusted with $\mathrm{NaOH}$. For $\mathrm{Ca}^{2+}$-free extracellular saline solution, $\mathrm{CaCl}_{2}$ was omitted and $100 \mu \mathrm{M}$ EGTA was added to remove contaminating free $\mathrm{Ca}^{2+}$. For an extracellular saline solution containing high $\mathrm{KCl}, \mathrm{NaCl}$ was replaced by equimolar $\mathrm{KCl}$. For whole-cell recordings, $10 \mathrm{~mm} \mathrm{NaCl}$ was replaced by $10 \mathrm{~mm}$ tetraethylammonium chloride (TEA-Cl) to block abundant delayed rectifier $\mathrm{K}^{+}$channels (Aguayo and Weight, 1988). Internal pipette solutions contained the following (in $\mathrm{mM}$ ): $125 \mathrm{KCl}$ or CsCl, 15 TEA-Cl, 5 HEPES, $1 \mathrm{MgCl}_{2}, 4 \mathrm{NaCl}, 10$ EGTA, pH 7.3 adjusted with $\mathrm{KOH}$ or $\mathrm{CsOH}$. For the experiment with impermeable $\mathrm{N}$-methylD-glucamine (NMDG) ions, $125 \mathrm{~mm} \mathrm{KCl}$ was replaced by equimolar NMDG-Cl in the internal solution. Some experiments used $\mathrm{SCN}^{-}$-based internal solution (in mM: $130 \mathrm{KSCN}, 10 \mathrm{TEA}-\mathrm{Cl}, 1 \mathrm{MgCl}_{2}, 10 \mathrm{EGTA}, 20$ HEPES, pH 7.3 adjusted with $\mathrm{KOH}$ ). EGTA and TEA were included in the internal solution to block $\mathrm{Ca}^{2+}$-activated or other $\mathrm{K}^{+}$channels. For the measurement of glutamate secretion, the extracellular saline solution contained the following (in mM): $128 \mathrm{NaCl}, 1.9 \mathrm{KCl}, 1.2 \mathrm{KH}_{2} \mathrm{PO}_{4}, 2.4$ $\mathrm{CaCl}_{2}, 1.3 \mathrm{MgSO}_{4}, 26 \mathrm{NaHCO}_{3}, 10$ D-glucose, 10 HEPES, pH 7.4 adjusted with $\mathrm{NaOH}$, and the $\mathrm{Ca}^{2+}$-free saline solution included $0.2 \mathrm{mM} \mathrm{CaCl}_{2}, 1$ mM EGTA, and $3.8 \mathrm{~mm} \mathrm{MgSO}_{4}$, whereas other components remained same.

Electrical recording and fast application of substrates. All current measurements were performed using the whole-cell configuration with an EPC-9 patch-clamp amplifier (HEKA Elektronik). When filled with internal solution, patch pipettes had a resistance of 4-6 M $\Omega$. The low-pass filter frequency was $1 \mathrm{kHz}$, and the sampling rate was $5 \mathrm{kHz}$.

For rapid application of agonists, we used a double-barreled pipette fabricated from theta glass tubing (outer diameter, $2.0 \mathrm{~mm}$; inner diameter, $1.4 \mathrm{~mm}$; $0.2 \mathrm{~mm}$ septum; Harvard Apparatus) and a Piezo-electric element (Noliac) (Dudel et al., 1990). The solution exchange time (20$80 \%$ ) was $500-800 \mu$ s when measured with an open patch pipette during a change between $100 \%$ saline and $10 \%$ saline solutions. To improve the solution exchange, recorded cells were lifted from the coverslip: After the rupture of the membrane patch, strong negative pressure ( $200 \mathrm{mbar})$ was maintained for 1-2 min to draw the nucleus to the patch pipette tip. The nucleated cells then could be lifted easily from the bottom and positioned in front of the rapid application system: Single isolated cells, especially ones of round shape, were not yet firmly attached to the substrate $1-2 \mathrm{~d}$ after plating. With the lifted cells, the solution exchange was estimated to take $2-3 \mathrm{~ms}$, as judged with $\mathrm{K}^{+}$currents during a switch of external $\mathrm{K}^{+}$concentrations from 137.5 to $2.5 \mathrm{~mm}$. In some experiments, rapid actuation of the theta tube perturbed the patched cell, and produced consistent but minor $(<1 \mathrm{pA})$ baseline fluctuations shortly before current activation (see Fig. $1 A$ ).

For perforated whole-cell recordings the patch pipettes were frontfilled with the normal internal solution and back-filled with the internal solution containing amphotericin B (Horn and Marty, 1988). Recordings started when input resistance became $<30 \mathrm{M} \Omega$. All patch-clamp measurements were made at room temperature $\left(22-24^{\circ} \mathrm{C}\right)$.

$\mathrm{Ca}^{2+}$ imaging. Intracellular $\mathrm{Ca}^{2+}$ concentration $\left(\left[\mathrm{Ca}^{2+}\right]_{\mathrm{i}}\right)$ was measured using the $\mathrm{Ca}^{2+}$-sensitive fluorescent dye fura-2. The cells were preincubated with $2 \mu \mathrm{M}$ membrane-permeable fura- $2 \mathrm{AM}$ in saline solution for $30 \mathrm{~min}$ at room temperature. Fluorescence in single pinealocytes was imaged using an inverted microscope (TE-300; Nikon) fitted with a 175 W xenon arc lamp, a Lambda 10-2 optical filter changer (Sutter), and a Coolsnap $f x$ CCD camera (Photometrics). The excitation wavelengths were 340 and $380 \mathrm{~nm}$, and fluorescence signals were recorded at $510 \mathrm{~nm}$ using Metafluor software (Universal Imaging). The sampling rate was 1 $\mathrm{Hz}$ and the background fluorescence measured from a cell-free area was subtracted. $\left[\mathrm{Ca}^{2+}\right]_{i}$ was calculated as described previously (Grynkiewicz et al., 1985; Herrington et al., 1996). For $\mathrm{Ca}^{2+}$ imaging experiments, solutions were exchanged by a local perfusion system that allowed complete exchange of medium within $0.5 \mathrm{~s}$ (Koh and Hille, 1997).

For $\mathrm{Ca}^{2+}$ measurements in pineal slices, fura-2 AM concentration and temperature were raised to $4 \mu \mathrm{M}$ and $37^{\circ} \mathrm{C}$, respectively, to facilitate the dye loading into compact tissues (Yuste, 2000). A small flat spatula was used to transfer pineal slices to the loading solution and the recording chamber to minimize damage to the circular agar block supporting the pineal slice. To achieve a relatively fast $(<1 \mathrm{~s})$ solution exchange, we designed a new chamber (see supplemental Fig. 3, available at www.jneurosci.org as supplemental material). Subtraction of background fluorescence and calibration of the dye could not be achieved in the slice dense with neighboring cells. Therefore, we present fluorescence ratios instead of calibrated $\left[\mathrm{Ca}^{2+}\right]_{\mathrm{i}}$ values. All $\mathrm{Ca}^{2+}$ imaging experiments were performed at room temperature $\left(22-24^{\circ} \mathrm{C}\right)$.

Measurement of exocytosis. Vesicular exocytosis was measured using carbon fiber amperometry as described previously (Kim et al., 2000). First, SLMVs of cultured pinealocytes were acutely loaded with oxidizable dopamine by fluid-phase endocytosis. This was accomplished by stimulating exocytosis and membrane recycling with a $\mathrm{K}^{+}$-rich solution for $2 \mathrm{~min}$ at room temperature in the presence of high concentrations of dopamine (in mu: 67.5 dopamine, $67.5 \mathrm{KCl}, 2 \mathrm{NaCl}, 2 \mathrm{CaCl}_{2}, 1 \mathrm{MgCl}_{2}$, 10 D-glucose, and 10 HEPES, pH 7.3 adjusted with $\mathrm{NaOH}$ ). In pinealocytes, the $\mathrm{KCl}$ stimulation evokes exocytosis preferentially of SLMVs instead of large dense-core vesicles containing serotonin (Yamada et al., 1996a, 2002). Cells were incubated for 5-10 $\mathrm{min}$ in a dopamine-free saline solution before measurements. Vesicular release of the loaded dopamine was monitored as pulses of electric current generated by oxidation of the molecules at the tip of the carbon fiber electrode polarized to $+400 \mathrm{mV}$ and gently touching a cell. Carbon fiber microelectrodes were fabricated from $11 \mu \mathrm{m}$ carbon fibers and polypropylene $10 \mu \mathrm{l}$ micropipettor tips (Koh and Hille, 1999). Amperometric currents were recorded with an EPC-9 amplifier, filtered at $100 \mathrm{~Hz}$, sampled at $500 \mathrm{~Hz}$, and later analyzed using a macro written in IGOR Pro (WaveMetrics). For amperometric experiments, solutions were exchanged within $0.5 \mathrm{~s}$ using a local perfusion system that warmed the solutions to $34-35^{\circ} \mathrm{C}$.

Measurement of glutamate and melatonin secretion. Pinealocytes $\left(10^{6}\right.$ cells per dish) were preincubated with $2 \mathrm{ml}$ of saline solution for $30 \mathrm{~min}$ and then challenged with $\mathrm{L}$ - or D-aspartate for $15 \mathrm{~min}$ at $37^{\circ} \mathrm{C}$. The released glutamate was determined by HPLC with precolumn $o$-phthalaldehyde derivatization, separation by a reverse-phase Resolve C18 column (4.6 $\times 150 \mathrm{~mm}$; Waters Ltd.), and fluorescence detection. Melatonin secreted from freshly dissected pineal glands was collected for $6 \mathrm{~h}$ at $37^{\circ} \mathrm{C}$ and measured using an ELISA kit (Alpco Diagnostics). Each measurement used one or two half-glands.

Data analysis. Analysis was performed with IGOR Pro (WaveMetrics). Concentration-response curves were fitted with the Hill equation: $f(c)$ $=1 /\left[1+\left(\mathrm{EC}_{50} / c\right)^{a}\right]$, where $c$ denotes substrate concentration, $\mathrm{EC}_{50}$ rep- 
resents the half-maximal effective concentration, and $a$ is the Hill coefficient. All numerical values are given as mean \pm SEM. The number of measured cells is indicated by $n$ in the text. Statistical difference of two groups was evaluated by Student's $t$ test. Probabilities of ${ }^{*} p \leq$ 0.01 or ${ }^{* *} p \leq 0.001$ were considered significant.

\section{Results}

General morphology and electrical properties of pinealocytes

Pinealocytes, the principal cell type in the pineal gland, were cultured for 1-2 d and visually identified by tiny spots on the cell surface (Yatsushiro et al., 2000), structures that may correspond to extensive surface membrane blebs observed by electron microscopy (Aguayo and Weight, 1988). In agreement with previous reports (Aguayo and Weight, 1988; Castellano et al., 1989), the pinealocytes selected this way exhibited both TEA (10 mM)-sensitive delayed rectifier and 4-AP (4-aminopyridine) (5 $\mathrm{mM}$ )-sensitive transient outward $\mathrm{K}^{+}$currents in dissociated preparations and in slices (for the transient $\mathrm{K}^{+}$currents, see Fig. $8 A$ ). Average membrane capacitance measured in the whole-cell patch configuration was $10.1 \pm 0.4 \mathrm{pF}(n=141)$.

\section{The pineal glutamate transporter conducts inward ionic currents} We begin by describing aspartate- and glutamate-induced currents in patched pinealocytes (Fig. 1). Many of the experiments use L-aspartate because it is a poor agonist for ionotropic glutamate receptors (iGluRs) yet is well transported by EAATs. Rapid application of L-aspartate to a lifted whole cell using a piezo-driven solution exchange system (see Materials and Methods) evoked small inward currents with an average peak current density of $1.1 \pm 0.1$ $\mathrm{pA} / \mathrm{pF}(n=18)$ at a holding potential of $-80 \mathrm{mV}$ (Fig. $1 A, B)$. With a $\mathrm{Cs}^{+}$-based internal solution, the current was transient, declining to the basal level with a time constant of $4.0 \pm 0.3 \mathrm{~ms}$. Currents activated by L-glutamate showed similar amplitudes and time courses. L-Glutamate is the endogenous agonist for iGluRs and is also well transported by EAATs. Typical iGluRs would show linear, outwardly, or doubly rectifying $I-V$ relationships reversing near $0 \mathrm{mV}$, with significant outward currents above $+40 \mathrm{mV}$ for most subtypes (Koh et al., 1995; Dingledine et al., 1999). In contrast, for both L-aspartate and L-glutamate, the pinealocyte currents were primarily inward, did not reverse at 0 $\mathrm{mV}$, and did not show large outward current at more positive potentials (Fig. $1 \mathrm{~A}$, current-voltage relationships). Such characteristics have been reported instead for currents in endogenous and cloned EAATs (Brew and Attwell, 1987; Eliasof and Werblin, 1993; Wadiche et al., 1995b; Bergles et al., 1997, 2002; Grewer et al., 2000). D-Aspartate also effectively induced current, whereas D-glutamate failed to do so (Fig. $1 B$ ). Dose-response curves for peak currents show that the three active amino acids evoke currents at high micromolar concentrations (Fig. 1C-E). Halfmaximal effective concentrations $\left(\mathrm{EC}_{50}\right)$ of $70-306 \mu \mathrm{M}$ are com- parable with those obtained with the GLT-1-type glutamate transporter of brain (Danbolt, 2001; Bergles et al., 2002) but higher than with the EAAC1 subtype (Grewer et al., 2000).

Although some properties of these currents, such as the rapid activation and decrease, are reminiscent of currents in iGluRs, the general features are more consistent with mediation by glutamate transporters. In accordance, several agonists of iGluRs such as NMDA $(n=13)$, AMPA $(n=6)$, and kainate (KA) $(n=7)$ failed to activate any current (Fig. $1 B$ ). In contrast, the same AMPA and kainate solutions (both $500 \mu \mathrm{M}$ ) routinely evoked $\sim 100 \mathrm{pA}$ of current mediated by AMPA-type glutamate receptors in pancreatic islet cells (J.-H. Cho and D.-S. Koh, unpublished observations). In addition, several antagonists of iGluRs failed to reduce the currents evoked by L-aspartate. The aspartate-evoked currents were not significantly reduced by a high concentration of 6-cyano-2,3-dihydroxy-7-nitro-quinoxaline (CNQX) (100 $\mu \mathrm{M})$, a specific blocker of AMPA-type glutamate receptors ( $94 \pm 24 \%$ of control at $V=-80 \mathrm{mV} ; n=3 ; p=0.16$ ), or by $50 \mu \mathrm{M}$ D-2-amino-5-phosphonopentanoate (D-AP5), a specific blocker of NMDA-type glutamate receptors $(103 \pm 26 \% ; n=3$; $p=0.52$ ).

We tested the L-aspartate-evoked currents for two known ionic features of EAAT currents: sensitivity to intracellular cations and sensitivity to intracellular anions. First, we consider the 


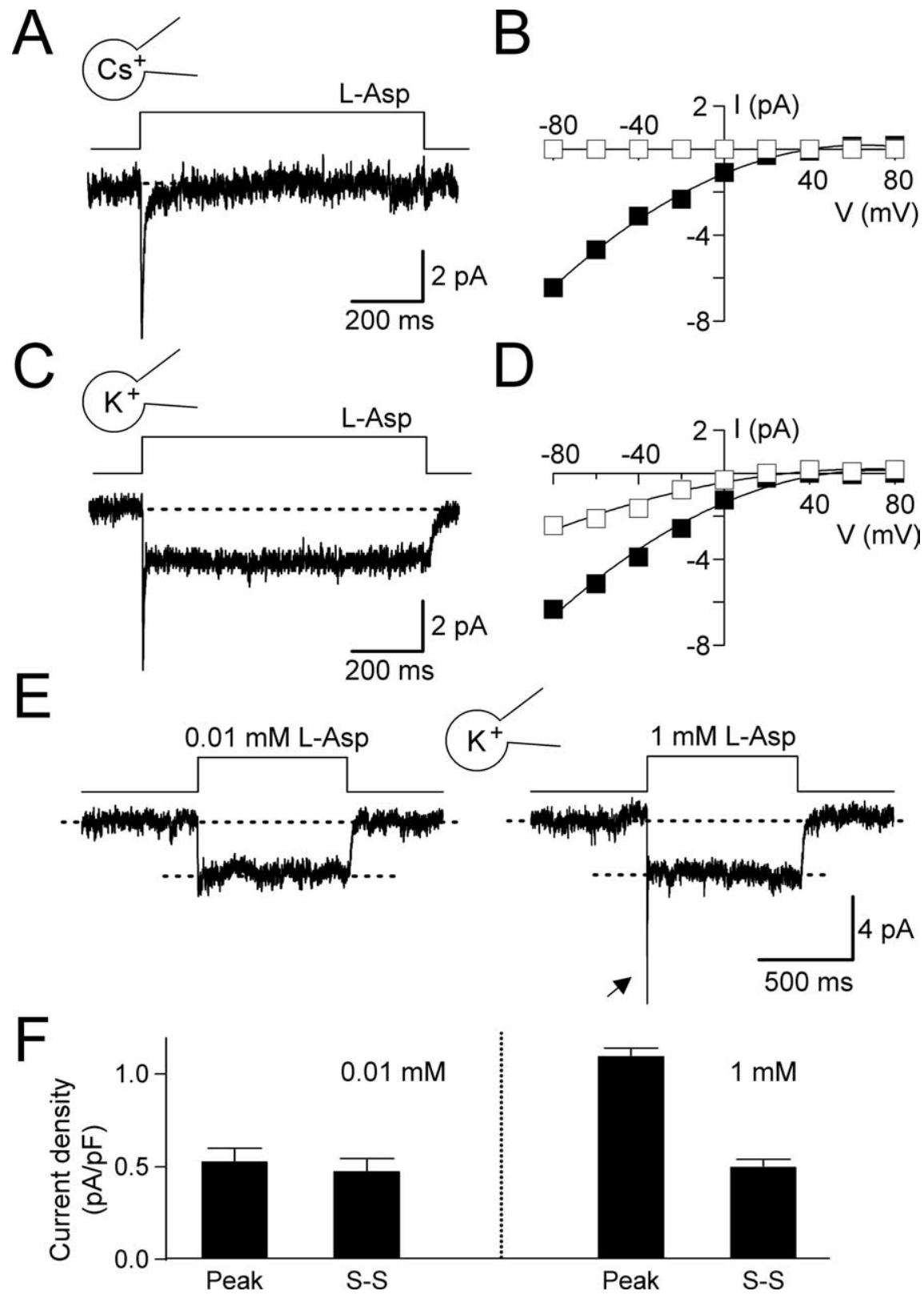

Figure 2. Steady inward currents require intracellular $\mathrm{K}^{+}$ions. Currents were activated by $1 \mathrm{~mm} \mathrm{~L}$-aspartate with $\mathrm{CsCl}(\boldsymbol{A})$ - or $\mathrm{KCl}(\boldsymbol{C})$-based internal solutions at $V=-80 \mathrm{mV}$ (different cells; means of 2-3 records). The dashed lines represent the basal current level. $\boldsymbol{B}, \boldsymbol{D}, I-V$ relationships of peak ( $\square$ ) and S-S currents ( $\square$; mean between 350 and $650 \mathrm{~ms}$ ) in the same cells as $A$ and $\boldsymbol{C}$. The lines are fitted third-order polynomials. $\boldsymbol{E}$, Currents were activated by 0.01 and $1 \mathrm{~mm} \mathrm{~L}$-aspartate with $\mathrm{KCl}$-based internal solution at $V=-80 \mathrm{mV}$ in the same cell. Traces are means of two to three records. The arrow indicates the peak current. $\boldsymbol{F}$, Average current density evoked by $0.01 \mathrm{~mm} \mathrm{~L}$-aspartate $(n=3)$ and $1 \mathrm{~mm} \mathrm{~L}$-aspartate $(n=9)$. Error bars indicate SEM.

half of the transport cycle and becomes stuck in an inwardly facing state. The half-cycle it completes would transport one aliquot of $\mathrm{Na}_{3} \mathrm{H}$-glutamate per transporter $(+3$ charges) inwardly. According to the Bergles model, $\mathrm{Cs}^{+}$ion catalyzes the return step poorly, seven times slower than $\mathrm{K}^{+}$. This fits with the transient L-aspartate-evoked currents we see with a $\mathrm{Cs}^{+}$-based pipette solution; they decayed almost completely within $15 \mathrm{~ms}(n=36)$ (Figs. $1 A, 2 A, B)$ at $-80 \mathrm{mV}$. However, with $\mathrm{K}^{+}$ion in the pipette, there was a considerable steady-state (S-S) current $(n=22)$ (Figs. 2C,D, 3), presumably as the transporter continued to cycle. This difference was apparent at all potentials. Similar residual S-S currents were observed with the EAAT substrates L-glutamate and D-aspartate (data not shown). As was also seen with heterologously expressed EAAC1 and GLT-1 transporters (Grewer et al., 2000; Bergles et al., 2002), the evoked peak and S-S currents had quite different sensitivities to L-aspartate (Fig. 2E,F). S-S currents were near maximal with $0.01 \mathrm{~mm}$ L-aspartate, whereas peak current was much increased in $1 \mathrm{~mm}$ L-aspartate.

Transporting capacity of the pineal glutamate transporter

Using the currents mediated by transporters we calculated a rough estimate of the number of functional transporters and their substrate turnover numbers in pinealocytes. We assume that current transients that decline to the baseline (e.g., peak currents with the internal $\mathrm{Cs}^{+}$solution) correspond to operation of a single half-cycle of inward glutamate transport that transfers a net three positive charges into the cell per transporter. Because $\mathrm{Cs}^{+}$ was suggested to support the full-cycle, albeit with a low cycling rate $(\sim 6 / \mathrm{s})$ (Bergles et al., 2002), we used an internal solution containing impermeant NMDG-Cl to block the outward transport completely. Average peak current activated by $1 \mathrm{~mm}$ L-aspartate at $-80 \mathrm{mV}$ was $0.9 \pm 0.1$ $\mathrm{pA} / \mathrm{pF}(n=3)$, and the current declined to the baseline with a time constant of $3.9 \pm$ cations and models for glutamate transporters. The transport cycle of GLT-1 (Levy et al., 1998; Bergles et al., 2002) and EAAC1 (Grewer et al., 2000) transporters has been described in terms of a complex kinetic model with multiple states of different orientation and different loading with $\mathrm{Na}^{+}, \mathrm{H}^{+}, \mathrm{K}^{+}$, and glutamate. At rest, the transporter is "outwardly facing." On addition of glutamate or aspartate the transporter picks up three $\mathrm{Na}^{+}$, one $\mathrm{H}^{+}$, and one glutamate. This complex makes a transition to cytoplasmically facing states that successively unload the substrates, pick up one cytoplasmic $\mathrm{K}^{+}$, and returns to the outwardly facing condition to complete the cycle. This final return step is supposed to be slow and rate-limiting for the transport cycle. Without intracellular $\mathrm{K}^{+}$, the transporter cannot complete the second one-
$0.3 \mathrm{~ms}$. Therefore, the half cycle takes $\sim 5 \mathrm{~ms}$, so the turnover number for the full cycle can be no more than 200/s. On addition of substrate at $-80 \mathrm{mV}$, we saw inward current transients that moved $\sim 5 \times 10^{-15}$ coulombs of charge per picofarad of membrane (the integral of the current transient is $5.2 \mathrm{fC} / \mathrm{pF}$ for L-aspartate). This corresponds to 31,000 electronic charges/pF crossing the cell membrane before all transporters become arrested in the inward facing configuration, or 310 charges $/ \mu \mathrm{m}^{2}$ (assuming $100 \mu \mathrm{m}^{2} / \mathrm{pF}$ for biological membranes). So we need at least 100 transporters $/ \mu \mathrm{m}^{2}$. This would be an underestimate if at $-80 \mathrm{mV}$ adding glutamate does not engage all the transporters in a complete half-cycle of transport. Indeed, it is probable that the three transported $\mathrm{Na}^{+}$ions have already been loaded before glu- 
tamate is delivered. This preloading of $\mathrm{Na}^{+}$reduces charge moved after glutamate delivery to 2.5 instead of 3 (Wadiche et al., 1995a), so the estimated number of transporters would rise to $120 / \mu \mathrm{m}^{2}$. Furthermore, some fraction of transporters might not bind $\mathrm{Na}^{+}$(Wadiche et al., 1995a).

What is the substrate turnover number? If the $0.5 \mathrm{pA} / \mathrm{pF}$ S-S current seen at $-80 \mathrm{mV}$ (with $\mathrm{K}^{+}$internal) is carried by 120 transporters passing a stoichiometric net charge of +2 per full cycle, then each transporter would transport $\sim 130$ glutamates/s. This rough estimate compares with that for GLT-1 (100/s) and EAAC1 or EAAT1 (66 and 17/s) (Wadiche and Kavanaugh, 1998; Bergles et al., 2002; Grewer and Rauen, 2005). The turnover rate is known to depend on intracellular $\mathrm{Na}^{+}$ and glutamate concentrations (Wadiche et al., 2006). Intracellular $\mathrm{Na}^{+}$and glutamate reduce turnover compared with $\mathrm{K}^{+}$ alone. Using SBFI (sodium-binding benzofuran isophthalate) as a fluorescent indicator of $\mathrm{Na}^{+}$in pinealocytes, we detected no cytoplasmic $\mathrm{Na}^{+}$increase $(n=17)$ on activation of glutamate transporter by $1 \mathrm{~mm}$ L-aspartate as long as $30 \mathrm{~s}$. In contrast, the $\mathrm{Na}^{+}$ionophore monensin $(20 \mu \mathrm{M})$ elicited significant increases of cytoplasmic $\mathrm{Na}^{+}$.

Together, pineal glutamate transporters would clear EAAs accumulated in the interstitial space in the pineal gland efficiently.

\section{Anion sensitivity and pharmacology of the pineal glutamate transporter}

Next, we consider the anion sensitivity of EAAT currents. The stoichiometric transport cycle of EAATs is accompanied by a nonstoichiometric anion conductance with the selectivity sequence, $\mathrm{SCN}^{-}>\mathrm{ClO}_{4}{ }^{-}>\mathrm{NO}_{3}{ }^{-}>\mathrm{I}^{-}>\mathrm{Br}^{-}>\mathrm{Cl}^{-}>\mathrm{F}^{-} \gg$ gluconate (Wadiche et al., 1995b; Wadiche and Kavanaugh, 1998; Danbolt, 2001; Bergles et al., 2002). In the glutamate transporter models, the nonstoichiometric conductance is associated with specific states of the active transporter (Grewer et al., 2000; Otis and Kavanaugh, 2000; Bergles et al., 2002). In the presence of transported substrates, even if nonstoichiometric current is not obvious when $\mathrm{Cl}^{-}$is the major anion, it should become more obvious when the solutions contain $\mathrm{NO}_{3}{ }^{-}$or $\mathrm{SCN}^{-}$. Correspondingly, switching from a KCl-based internal solution to a KSCN-based one, increased the L-aspartate-evoked peak current density $(8.9 \pm 1.5 \mathrm{pA} / \mathrm{pF} ; n=11)$ and the S-S current in pinealocytes approximately eightfold (Fig. $3 A, B$ ).

If the evoked currents are carried by EAATs, they should be sensitive to the competitive EAAT inhibitors, dihydrokainate (DHK) and DL-threo- $\beta$-benzyloxyaspartate (TBOA). $\mathrm{SCN}^{-}$mediated currents were evoked by $1 \mathrm{~mm}$ L-aspartate in the absence and presence of $300 \mu \mathrm{M}$ DHK (Fig. $3 A, C$ ). The peak response with KSCN was significantly blocked by DHK, but the S-S response was slightly increased. Exactly the same paradoxical effect has been reported for heterologously expressed EAAC1 and GLT-1 (Grewer et al., 2000; Bergles et al., 2002). The effect has been explained and modeled: DHK occupies the transporters at rest and prevents the initial synchronous conversion to a highconducting state (peak current) on application of amino acid substrate; however, within a few milliseconds the DHK molecules dissociate and are competitively replaced by substrate, so the transporter returns to full steady-state operation. The evoked steady-state current appears larger than in control because the DHK had also blocked a small standing inward anion leak current at rest (already enhanced by $\mathrm{SCN}^{-}$); subsequent binding of the amino acid substrate restores this missing component of inward current as well. The lack of DHK block of S-S currents evoked by $1 \mathrm{~mm}$ L-aspartate might appear inconsistent with previous results obtained with GLT-1 (EAAT2) overexpressed in oocytes (Arriza et al., 1994; Wadiche et al., 1995a) where currents (presumably S-S current attributable to slow agonist application to oocytes) evoked by low $(100 \mu \mathrm{M})$ L-glutamate were significantly blocked by DHK and kainate. However, DHK and kainate are competitive blockers so their blocking action depends on the relative concentrations of agonist and antagonist. In line with this explanation, with low concentrations of L-glutamate $(100 \mu \mathrm{M})$ the S-S currents of the pineal glutamate transporters were significantly blocked by $500 \mu \mathrm{M}$ DHK (relative current compared with control, $0.15 \pm$ $0.08 ; n=3)$ and kainate $(0.21 \pm 0.03 ; n=5)$. TBOA $(300 \mu \mathrm{M})$ depressed both peak and S-S currents (Fig. $3 A, C$ ). The block by DHK and TBOA was fully reversible (data not shown).

\section{Glutamate transporter-mediated currents depolarize the membrane and increase intracellular $\mathrm{Ca}^{2+}$}

Pinealocytes express L-type $\mathrm{Ca}^{2+}$ channels that are responsible for exocytosis of SLMVs containing L-glutamate and L-aspartate (Yatsushiro et al., 1997). Can inward transporter currents evoked by these transmitters depolarize the membrane potential enough to activate voltage-dependent $\mathrm{Ca}^{2+}$ channels and consequently increase intracellular $\mathrm{Ca}^{2+}$ concentration $\left(\left[\mathrm{Ca}^{2+}\right]_{\mathrm{i}}\right)$ ? To address this question, we first measured the membrane potential of pinealocyte in perforated whole-cell configuration. In the currentclamp mode with no current injection, the resting membrane potential was $-45 \pm 3 \mathrm{mV}(n=7)$. Because pinealocytes have a high input resistance (see below), we included only those cells with seal resistance $>1 \mathrm{G} \Omega$ in the analysis for a reliable estimation of the membrane potential. Significant fluctuation of the resting 


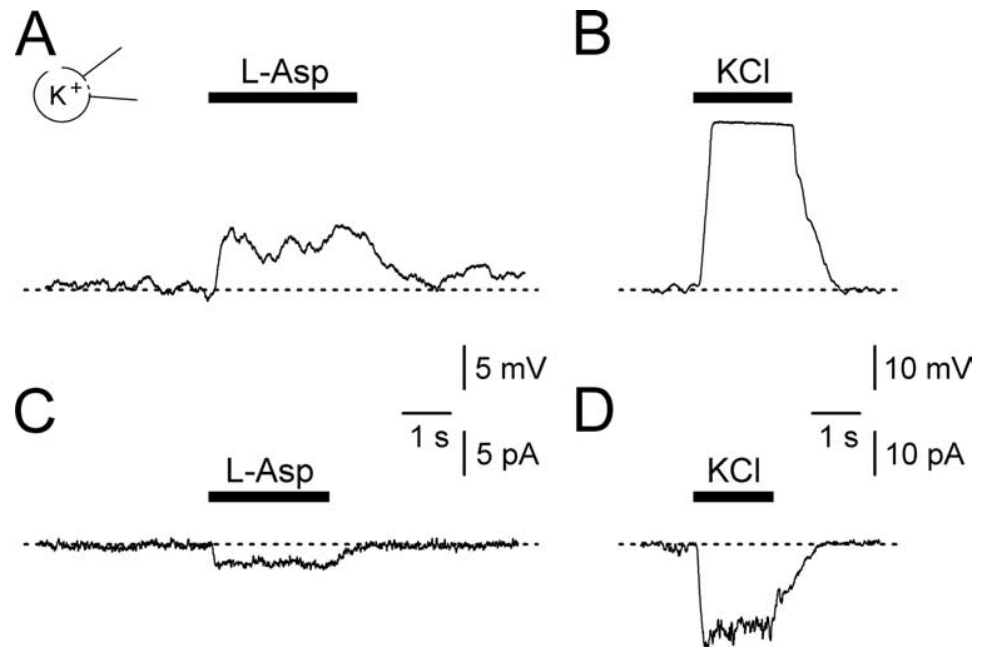

Figure 4. Depolarization of the membrane potential by glutamate transporter-mediated currents. $A, B$, Membrane depolarizations evoked by $1 \mathrm{mmL}$-aspartate and $50 \mathrm{~mm} \mathrm{KCI}$ (current-clamp mode). $\boldsymbol{C}, \boldsymbol{D}$, Membrane currents evoked by L-aspartate and KCl (voltage-clamp mode at $V=-60 \mathrm{mV}$ ). All recordings were from the same cell in the perforated whole-cell configuration.

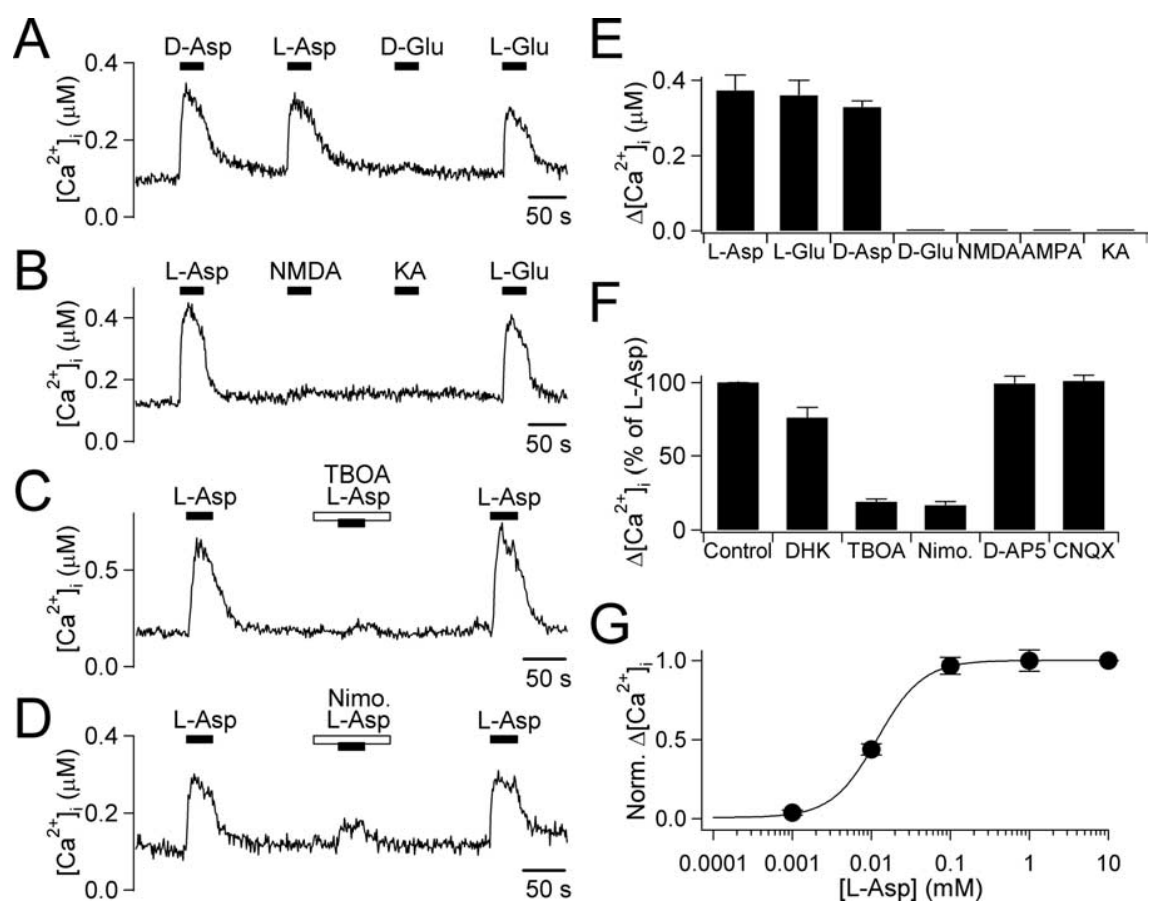

Figure 5. $\left[\mathrm{Ca}^{2+}\right]_{\mathrm{i}}$ rise induced by glutamate transporters. Ratiometric calcium traces as agonists at $1 \mathrm{~mm}$ (except AMPA and kainate, $0.5 \mathrm{~mm}$ ) were applied for $30 \mathrm{~s}$ using a local perfusion system (exchange within $0.5 \mathrm{~s}$ ). $\boldsymbol{A}, \boldsymbol{B}$, Three transporter substrates evoked $\mathrm{Ca}^{2+}$ responses. D-Glutamate and two specific agonists of iGluR did not. C, D, TBOA (300 $\mu \mathrm{M})$ and nimodipine $(5 \mu \mathrm{M})$ reduced the $\left[\mathrm{Ca}^{2+}\right]_{\mathrm{i}}$ rise induced by $1 \mathrm{~mm}$ L-aspartate. DHK at the same concentration were less effective (shown in $\boldsymbol{F}$ ). $\boldsymbol{E}$, Summary of experiments like $\boldsymbol{A}$ and $\boldsymbol{B}$. $\boldsymbol{F}$, Summary of experiments like (and $\boldsymbol{D}$, normalized to L-aspartate alone; DHK (300 $\mu \mathrm{m} ; n=21)$, TBOA $(n=30)$, nimodipine $(n=14), 50$ $\mu \mathrm{MD}-\mathrm{AP5}(n=10)$, or $10 \mu \mathrm{M}$ CNQX $(n=13)$. G, Dose-response relationship for L-aspartate evoked Ca ${ }^{2+}$ responses $(n=38-54$ for each concentration). $\mathrm{EC}_{50}$ and Hill coefficient are $12 \mu \mathrm{m}$ and 1.5. Error bars indicate SEM.

membrane potential was observed, reflecting a high input resistance and a small $\mathrm{K}^{+}$leakage conductance responsible underlying the resting potential. Then the cells were perfused with $1 \mathrm{~mm}$ $\mathrm{L}$-aspartate via a local application system (exchange time, $<0.5 \mathrm{~s}$ ) (see Materials and Methods) (local solution exchange was used because we could not lift perforated whole cells). The neurotransmitter depolarized the membrane by $9 \pm 2 \mathrm{mV}(n=3)$ (Fig. $4 A$ ). In the same cells, the evoked transporter current was $4 \pm 1 \mathrm{pA}$ $(n=3$; at $-60 \mathrm{mV})$ using voltage-clamp mode (Fig. $4 C)$. Hence the membrane depolarization during L-aspartate application was induced by S-S transporter currents and pinealocytes have a high input resistance. An extracellular solution containing $50 \mathrm{~mm} \mathrm{KCl}$ depolarized the membrane by $32 \pm 7 \mathrm{mV}$ as expected from the Nernst equation $(n=3)$ (Fig. $4 B$ ), and the $\mathrm{K}^{+}$inward current elicited at -60 $\mathrm{mV}$ was $43 \pm 19 \mathrm{pA}(n=3)($ Fig. $4 D)$.

Next, we tested whether the small depolarization induced by the transporter is enough to activate voltage-gated $\mathrm{Ca}^{2+}$ channels and can increase $\left[\mathrm{Ca}^{2+}\right]_{\mathrm{i}}$ (Fig. 5). The average resting $\left[\mathrm{Ca}^{2+}\right]_{\mathrm{i}}$ measured with $\mathrm{Ca}^{2+}$-sensitive dye fura- 2 was $101 \pm$ $4 \mathrm{~nm}(n=114)$. On application of $1 \mathrm{~mm}$ L-aspartate using the same local perfusion system as for measurement of the membrane potential, $\left[\mathrm{Ca}^{2+}\right]_{\mathrm{i}}$ increased to a peak within a few seconds and then declined slowly (Fig. 5A-D). Most cells responded to L-aspartate (102 of 118 cells; $373 \pm 41 \mathrm{nM} \mathrm{Ca}^{2+}$ increase in responding cells), L-glutamate ( 29 of $33 ; 360 \pm 41 \mathrm{nM})$, and D-aspartate (11 of $13 ; 328 \pm 17 \mathrm{~nm}$ ), but no cells responded to the iGluR agonists D-glutamate (0 of 13), NMDA (0 of 11 ), AMPA (0 of 26), or kainate (0 of 13 ) (Fig. $5 B, E$ ). This agonist profile is identical to that for the glutamate transportermediated currents in Figure $1 B$.

Pharmacological experiments confirmed that the $\mathrm{Ca}^{2+}$ rise evoked by L-aspartate required glutamate transporters. The $\mathrm{Ca}^{2+}$ rise was blocked reversibly by TBOA and, to a lesser extent, by DHK (Fig. 5C,F) consistent with the transporter current measurements (Fig. 3). The L-aspartate-evoked $\mathrm{Ca}^{2+}$ response was not sensitive to the antagonists of NMDA- and AMPA-type receptors, D-AP5 and CNQX (Fig. $5 F$ ). Efficient block by $5 \mu \mathrm{M}$ nimodipine identified the major pathway of $\mathrm{Ca}^{2+}$ influx as an L-type $\mathrm{Ca}^{2+}$ channel (Fig. $5 D, F$ ), suggesting that the glutamate transporter itself has little $\mathrm{Ca}^{2+}$ permeability, as previously reported (Danbolt, 2001). The same concentration of nimodipine also blocked the $\mathrm{Ca}^{2+}$ rise induced by L-glutamate $(n=9)$ (data not shown). The $\mathrm{Ca}^{2+}$ rise was not attributable to activation of endogenous mGluRs triggering $\mathrm{Ca}^{2+}$ release from internal $\mathrm{Ca}^{2+}$ stores because L-glutamate evoked the $\mathrm{Ca}^{2+}$ response only in the presence of external $\mathrm{Ca}^{2+}$ (supplemental Fig. $1 A$, available at www.jneurosci.org as supplemental material). In addition, even in cells treated with thapsigargin to deplete the internal $\mathrm{Ca}^{2+}$ stores, the $\mathrm{Ca}^{2+}$ rise by $\mathrm{L}$-aspartate was comparable with the control [compare supplemental Fig. $1 B$ (available at www.jneurosci.org as supplemental material), Fig. $5 A$ ]. This result again indicates that $\mathrm{Ca}^{2+}$ influx through depolarization-activated $\mathrm{Ca}^{2+}$ channels was the major source for cytoplasmic $\mathrm{Ca}^{2+}$ rise evoked by L-aspartate. 
Interestingly, the $\mathrm{Ca}^{2+}$ rise was significant even at low concentrations of L-aspartate (Fig. $5 G$ ) with an $\mathrm{EC}_{50}(12 \mu \mathrm{M})$ about eight times lower than that for L-aspartate-evoked peak currents (Fig. 1C). This result implies that S-S inward currents activated at low concentrations of EAAT substrates (Fig. $2 E, F$ ) depolarize the membrane enough to activate voltage-gated $\mathrm{Ca}^{2+}$ channels significantly.

\section{The $\mathrm{Ca}^{2+}$ rises evoke glutamate release via exocytosis}

$\mathrm{Ca}^{2+}$ triggers exocytosis of SLMVs in many endocrine cells, including pinealocytes (Yamada et al., 1996a). We address whether the L-aspartate-evoked $\left[\mathrm{Ca}^{2+}\right]_{\mathrm{i}}$ rise suffices to evoke L-glutamate secretion from SLMVs in pinealocytes. Before the measurements, SLMVs were preloaded with oxidizable dopamine as described in Materials and Methods and exocytosis was detected by carbon fiber amperometry (Fig. 6). Oxidation of dopamine released from each vesicle was recorded as an oxidative current spike (Fig. $6 \mathrm{~A}$ ); amperometry indirectly reports the release of L-glutamate from SLMVs. Addition of $1 \mathrm{mM} \mathrm{L}$-aspartate increased the frequency of these amperometric signals. To quantify the rate of exocytosis, we counted the number of amperometric spikes per $30 \mathrm{~s}$ time bin and normalized this rate to the mean rate in control solution (Fig. 6B). Relative exocytosis, calculated as the mean values of normalized exocytosis, was $2.5 \pm 0.4(n=11)$ during 2 min of $\mathrm{L}$-aspartate application (Fig. $6 B, D$ ). This stimulation was significantly depressed by $300 \mu \mathrm{M}$ TBOA, confirming that the exocytosis is initiated by the activation of glutamate transporters (relative exocytosis for 2 min, $1.3 \pm 0.3 ; n=19$ ) (Fig. 6C,D). In contrast, $1 \mathrm{~mm}$ kainate failed to induce exocytosis, again indicating no activation of AMPA/kainate receptors in pinealocytes (relative exocytosis for $2 \mathrm{~min}, 1.1 \pm 0.2 ; n=3$ ) (Fig. 6D).

We also measured evoked secretion of L-glutamate directly using HPLC (Fig. 7). L-Glutamate secretion was augmented 5.9fold ( $n=10$ independent measurements) when cells were treated with $100 \mu \mathrm{M} \mathrm{L}$-aspartate. As expected, this glutamate secretion was significantly reduced by the transporter blockers DHK and TBOA, by blocking L-type $\mathrm{Ca}^{2+}$ channels with nimodipine, and by removing extracellular $\mathrm{Ca}^{2+}$. Glutamate secretion also was sensitive to blocking vesicular proton pumps with bafilomycin $\mathrm{A}_{1}$ and to blocking vesicle fusion with botulinum neurotoxin type $\mathrm{E}$ (BoNT/E), as reported for the exocytosis of pineal SLMVs (Yatsushiro et al., 1997). It was not sensitive to blockers of glutamate receptors including (+)-5-methyl-10,11-dihydroxy-5H-dibenzo $(a, d)$ cyclohepten5,10-imine (MK-801) (a specific blocker of NMDA receptor) and CNQX. Similar results were obtained when D-aspartate was used to stimulate pinealocytes (supplemental Fig. 2, available at www. jneurosci.org as supplemental material). Together, these results confirm that aspartate-evoked increases in intracellular $\left[\mathrm{Ca}^{2+}\right]$ can trigger release of L-glutamate by vesicular exocytosis.

\section{Activation of glutamate transporters in the pineal gland}

We now test whether EAAs, L-glutamate, and L- and D-aspartate "excite" cellular responses via the glutamate transporter in freshly prepared pineal slices. Because measurement of glutamate transporters in cells positioned deep inside pineal slices suffers from slow agonist application, we studied cells on the surface of the slice. For electrophysiological experiments, we relied on a characteristic electrophysiological criterion to identify the cells: Pinealocytes but not glial cells express large transient and TEAinsensitive $\mathrm{K}^{+}$currents activated at more than $-20 \mathrm{mV}$ (Aguayo and Weight, 1988; Castellano et al., 1989).

We began by checking for the functional presence of glutamate transporters in the acutely prepared pineal slices. Internal

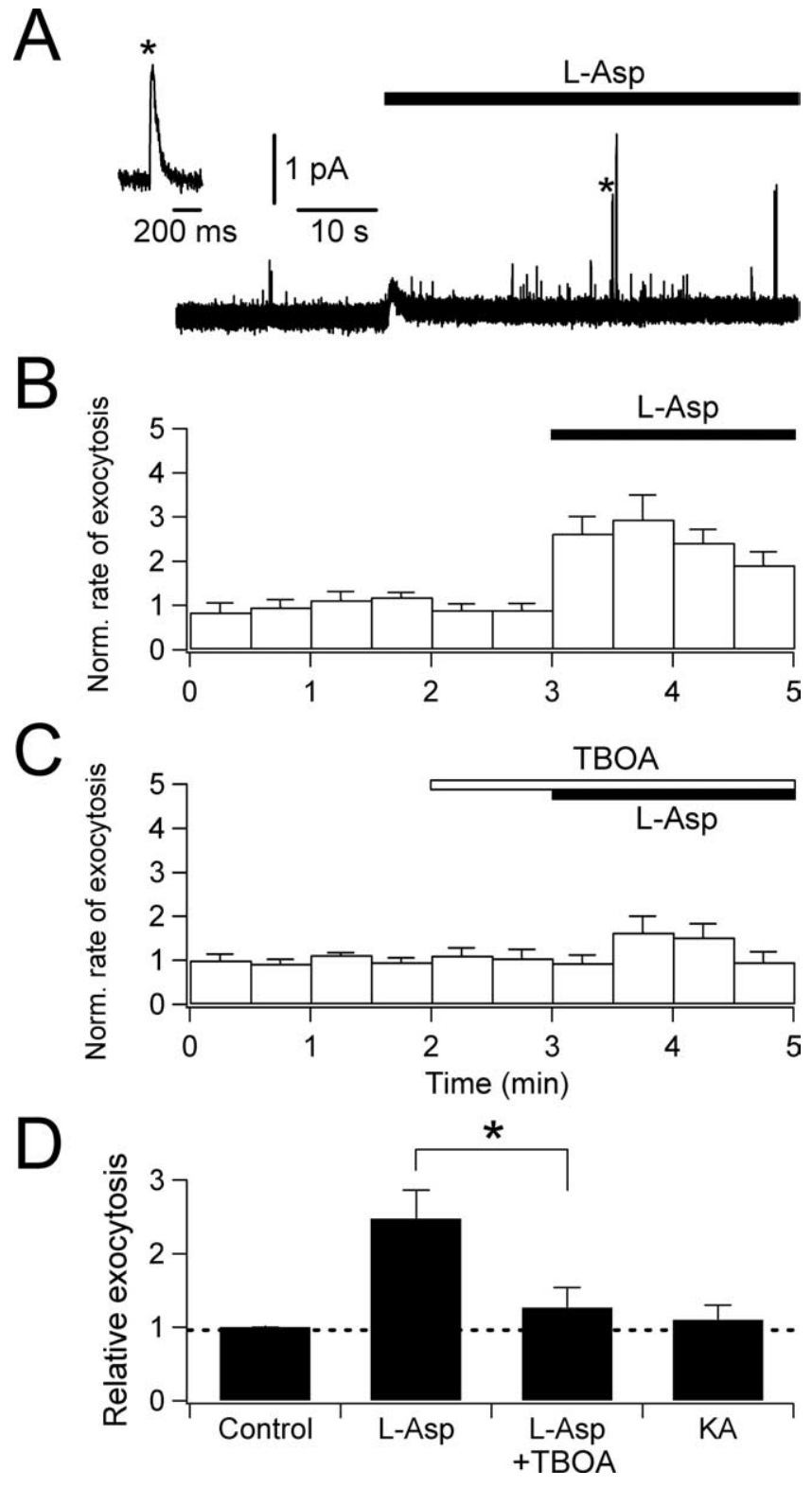

Figure 6. L-Aspartate-evoked exocytosis monitored by carbon fiber amperometry. $\boldsymbol{A}, \mathrm{An}$ amperometric trace demonstrating increase in exocytotic events after $1 \mathrm{~mm}$ L-aspartate application (marked by a transient deflection of base line). Inset, 0 ne spike denoted by an asterisk is expanded to show a typical quantal release. $\boldsymbol{B}$, Rate of exocytosis in $30 \mathrm{~s}$ bins normalized to the control (average of 11 cells). $C$, Inhibition by $300 \mu \mathrm{M}$ TBOA (average of 19 cells). D, Summary of exocytosis evoked by $1 \mathrm{~mm} \mathrm{~L}$-aspartate alone $(n=11), 1 \mathrm{~mm}$ L-aspartate in the presence of 300 $\mu \mathrm{M} \mathrm{TBOA} \mathrm{(} n=19$; ${ }^{*} p<0.01$ compared with L-aspartate alone), and $1 \mathrm{~mm} \mathrm{KA}(n=3)$. Error bars indicate SEM.

KSCN solution was used to increase the anion conductance of the transporters. All pinealocytes identified in slices by the $\mathrm{K}^{+}$current criterion exhibited transporter-mediated currents when L-aspartate was applied $(n=21)$ (Fig. $8 A$ ). Slowed substrate access obscured any transient peak in the response. The mean S-S current evoked by $1 \mathrm{~mm}$ L-aspartate was $4.4 \pm 0.3 \mathrm{pA} / \mathrm{pF}$ (with KSCN internal) at $-60 \mathrm{mV}$, comparable with that in cultured single cells (Fig. 3), and it was reversibly reduced by TBOA. Incubation with TBOA alone reduced the background inward current level as well as it did in cultured cells. As for isolated-cell experiments (Fig. $1 B$ ), 1 mM NMDA evoked no current, indicating no functional NMDA receptors in pineal slices. Another agonist of NMDA receptors, $1 \mathrm{~mm}$ D-aspartate, induced average S-S 


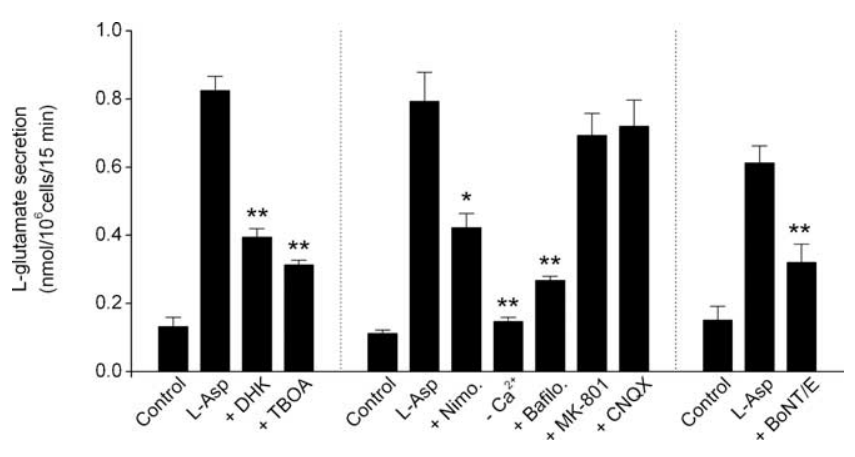

Figure 7. L-Aspartate-evoked L-glutamate secretion monitored by HPLC. L-Glutamate release evoked by $100 \mu \mathrm{m}$ L-aspartate in the absence and presence of different blockers: blockers of glutamate transporters (500 $\mu \mathrm{m}$ DHKand $100 \mu \mathrm{MTBOA})$, an L-type $\mathrm{Ca}^{2+}$ channel blocker (20 $\mu \mathrm{M}$ nimodipine), removal of extracellular $\mathrm{Ca}^{2+}\left(-\mathrm{Ca}^{2+}\right)$, a vesicular $\mathrm{H}^{+}$-pump inhibitor (1 $\mu \mathrm{m}$ bafilomycin $\mathrm{A}_{1}$ ), iGluR inhibitors ( $10 \mu \mathrm{m}$ MK-801 and $50 \mu \mathrm{m}$ (NQX), or an exocytosis toxin (10 nм BoNT/E, preincubated for $24 \mathrm{~h}$ ). Shown are means of three to four independent experiments ( ${ }^{*} p<0.01,{ }^{* *} p<0.001$, compared with L-aspartate alone). Error bars indicate SEM.

currents of $0.5 \pm 0.3 \mathrm{pA} / \mathrm{pF}$ at $-60 \mathrm{mV}$ (with $\mathrm{KCl}$ internal; $n=3$ ) apparently mediated by glutamate transporters. In the presence of $100 \mu \mathrm{M}$ cyclothiazide, a blocker of desensitization of AMPAtype glutamate receptors, the S-S current with L-glutamate (1 $\mathrm{mM})$ was $0.5 \pm 0.1 \mathrm{pA} / \mathrm{pF}$ at $-60 \mathrm{mV}(n=3)$, no larger than the expected glutamate transporter-mediated currents. With the same cyclothiazide conditions in dissociated cultured cells, the $\mathrm{S}-\mathrm{S}$ current was $0.5 \pm 0.1 \mathrm{pA} / \mathrm{pF}(n=6)$. Hence, glutamate transporters are expressed in these more intact pineal slices, whereas there was no evidence for functional AMPA and NMDA receptors.

Next, cells in pineal slices were loaded with the $\mathrm{Ca}^{2+}$-sensitive fluorescent dye fura-2 AM and challenged with different substrates in a chamber designed to apply the molecules rapidly to the surface of the slice (supplemental Fig. 3, available at www. jneurosci.org as supplemental material). Most cells in a slice showed $\mathrm{Ca}^{2+}$ rises activated by substrates of glutamate transporters, but the peak $\mathrm{Ca}^{2+}$ response to $1 \mathrm{mM}$ L-aspartate or L-glutamate was quite variable, presumably because not all cells had good access to the applied molecules. The following arguments indicate that these responses are mainly attributable to glutamate transporters and not to AMPA-type iGluRs: Several cells $(\sim 10 \%)$ in each slice showed large $\mathrm{Ca}^{2+}$ rises during application of $1 \mathrm{mM} \mathrm{L}$-aspartate or L-glutamate, but not of AMPA or kainate (supplemental Fig. $4 A, D$, available at www.jneurosci.org as supplemental material). Furthermore, L-glutamate evoked responses no greater than those with L-aspartate, as was observed in dissociated cultured cells (Fig. 5A,B,E). Finally, the $\mathrm{Ca}^{2+}$ responses were significantly inhibited by TBOA and unaffected by CNQX (supplemental Fig. 4B, C,E, available at www.jneurosci. org as supplemental material).

\section{Glutamatergic paracrine interactions in pineal slices}

Glutamate transporters, when activated by exogenous EAAs, supported significant $\mathrm{Ca}^{2+}$ rise and glutamate release from pinealocytes. We reasoned that transporters might be activated by the EAAs released from neighboring cells (Fig. $8 B$, inset). Release of EAAs from the surrounding cells was evoked by an external solution containing $50 \mathrm{~mm} \mathrm{KCl}$ to depolarize the membrane (Fig. $4 B, D)$, increase $\left[\mathrm{Ca}^{2+}\right]_{\mathrm{i}}$ (supplemental Fig. $6 A$, available at www.jneurosci.org as supplemental material), and evoke EAA release (Yamada et al., 2002). Activity of the transporters was monitored electrically using the KSCN internal solution (Fig.
$8 B)$. In this condition, two types of inward current were expected during the $\mathrm{KCl}$ application: augmented transporter current and $\mathrm{K}^{+}$inward current. $\mathrm{KCl}$ applied to the slice induced an inward current of $2.6 \pm 0.4 \mathrm{pA} / \mathrm{pF}(n=7)$, which could be reduced by $54 \pm 6 \%$ with $300 \mu \mathrm{M}$ TBOA. The remaining current after TBOA was apparently TEA-insensitive $\mathrm{K}^{+}$current. The current activated by $135 \mathrm{~mm} \mathrm{KCl}$ was larger and often quite fluctuating (variance, $66.2 \pm 24.0 \mathrm{pA}^{2} ; n=4$; compared with control, $5.2 \pm 1.6$ $\mathrm{pA}^{2}$ ) (Fig. 8C). We interpret the noisy current during $135 \mathrm{~mm}$ $\mathrm{KCl}$ stimulation as caused by overlapping transient transporter currents activated by quantal release of EAAs from the neighboring pinealocytes. In summary, the EAAs released by $\mathrm{KCl}$ stimulation from pinealocytes can activate glutamate transporters in neighboring cells in the compact pineal gland.

Because we had observed "glutamate-induced glutamate release" in single pinealocytes, we asked whether the endogenous EAAs released by $\mathrm{KCl}$ stimulation from a pinealocyte could evoke release of EAAs from other neighboring cells. Such a chain reaction would result in propagation of EAA release inside the pineal gland. To test the possibility, we designed a chamber (supplemental Fig. 5, available at www.jneurosci.org as supplemental material) to allow us to apply $50 \mathrm{~mm} \mathrm{KCl}$ to one side of a pineal slice and to monitor $\mathrm{Ca}^{2+}$ signals on the opposite side (Fig. 9A). Pineal slices were loaded with fura-2 dye and installed in the chamber. Insertion of the inner chamber covered the top of the slice except for a hole of $\sim 400 \mu \mathrm{m}$. With thin slices (150-200 $\mu \mathrm{m})$, application of $50 \mathrm{mM} \mathrm{KCl}$ to the slice through the hole frequently increased $\mathrm{Ca}^{2+}$ in pinealocytes on the bottom (8 of 13 tested slices) (Fig. 9C). With thicker slices (250-300 $\mu \mathrm{m}), \mathrm{KCl}$ did not evoke any $\mathrm{Ca}^{2+}$ signals in cells on the bottom $(n=5)$ (Fig. 9B). The $\mathrm{Ca}^{2+}$ signals were abolished by TBOA (relative $\mathrm{Ca}^{2+}$ rise compared with the control response; $0.05 \pm 0.03 ; n=$ $5)$, suggesting that EAA signals propagated through several cell layers via glutamate transporter signals. Pineal slices are compactly packed with pinealocytes and have a high density of binding sites for TBOA (i.e., glutamate transporters). Therefore, we took several precautions to ensure that TBOA was able to reach the glutamate transporters in the slice: (1) The TBOA concentration was increased to $600 \mu \mathrm{M}, 100$-fold higher than needed for half-maximal inhibition of EAAT2 $\left(K_{\mathrm{i}}=5.7 \mu \mathrm{M}\right)$ (Shimamoto et al., 1998). (2) Slices were preincubated in TBOA for $6 \mathrm{~min}$. Note also that TBOA has a small molecular weight (239.2), comparable with acetylcholine (ACh) (181.7). The possibility that TBOA blocks $\mathrm{KCl}$-induced $\mathrm{Ca}^{2+}$ responses of the top cells was excluded in $\mathrm{Ca}^{2+}$ imaging experiments using cultured single pinealocytes (relative $\mathrm{Ca}^{2+}$ rise in the presence of $600 \mu \mathrm{M}$ TBOA compared with the control $\mathrm{KCl}$ response; $0.86 \pm 0.03 ; n=8$ ) (supplemental Fig. 6A, available at www.jneurosci.org as supplemental material).

The pineal gland is innervated with cholinergic nerve terminals (Phansuwan-Pujito et al., 1999). Pinealocytes also express nicotinic acetylcholine receptors and their activation results in membrane depolarization, $\mathrm{Ca}^{2+}$ rise, and glutamate secretion (Letz et al., 1997; Yamada et al., 1998b). Therefore, we tested whether EAAs released by ACh also evoked a propagating signal. In single cells, $200 \mu \mathrm{M}$ ACh increased $\left[\mathrm{Ca}^{2+}\right]_{\mathrm{i}}(1.3 \pm 0.3 \mu \mathrm{M} ; n=$ 22) as efficiently as $50 \mathrm{~mm} \mathrm{KCl}$. In pineal slices, the ACh stimulation was able to initiate the propagating EAA signals (11 of 16 tested slices; $140-180 \mu \mathrm{m}$ ) (Fig. 9D). Again, the $\mathrm{Ca}^{2+}$ signals were significantly reduced by $600 \mu \mathrm{M}$ TBOA (relative $\mathrm{Ca}^{2+}$ rise compared with control; $0.33 \pm 0.07 ; n=10$ ). There was a time delay $(\sim 10 \mathrm{~s})$ between the $\mathrm{KCl} / \mathrm{ACh}$ stimulations and $\mathrm{Ca}^{2+}$ rise 
at the bottom of the slices, presumably reflecting a slow cell-to-cell propagation rate.

In Discussion, we consider the stimulation of melatonin synthesis by norepinephrine (NE) and a negative feedback on that stimulation by L-glutamate. Our working hypothesis is that a propagating glutamate signal inhibits melatonin synthesis via inhibitory metabotropic glutamate receptor (Kus et al., 1994; Yamada et al., 1997a, 1998a; Ishio et al., 1998). A preliminary experiment (Fig. 10) indicates that the inhibition of melatonin secretion requires glutamate transporters. Melatonin secretion evoked by $10 \mu \mathrm{M}$ NE from intact pineal glands was inhibited by 500 $\mu \mathrm{M}$ L-aspartate. This inhibition by L-aspartate was blocked by $300 \mu \mathrm{M}$ TBOA $(p<0.01$, compared with NE plus L-aspartate).

\section{Discussion}

Properties and functions of pineal glutamate transporters

In excitatory synapses of the CNS, glutamate activates iGluRs, transiently depolarizing and increasing the excitability of the postsynaptic membrane (McBain and Mayer, 1994; Dingledine et al., 1999). Apparently, in pinealocytes, a similar function is performed by glutamate transporters while they clear excitatory neurotransmitters released from other cells. In this study, we conclude that EAA-evoked responses of pinealocytes are mainly mediated by the glutamate transporter not by iGluR for the following reasons: (1) They are almost equally activated by L-glutamate and L- or D-aspartate; (2) they are insensitive to iGluR agonists and antagonists; (3) they are sensitive to transporter blockers; (4) there are no outward currents; (5) S-S currents are dependent on the internal $\mathrm{K}^{+}$; and (6) the conductance increases when $\mathrm{Cl}^{-}$is replaced by $\mathrm{SCN}^{-}$. These properties were shown in isolated pinealocytes, and most were also shown with pineal slices.

Which subtype of glutamate transporters is expressed in pinealocytes? The pineal transporters exhibit many of the known properties of glutamate transporters (Grewer et al., 2000; Otis and Kavanaugh, 2000; Bergles et al., 2002; Tzingounis and Wadiche, 2007). We previously demonstrated with reverse transcription-PCR, Northern and Western blots, and immunocytochemistry that pinealocytes express glutamate transporters of the GLT-1-type and not GLAST or EAAC1 (Yamada et al., 1997b). In agreement, we find here that pineal glutamate transporters are readily inhibited by DHK, which blocks GLT-1 at concentrations 130-fold lower than for GLAST or EAAC1 (Arriza et al., 1994). Thus, we favor the hypothesis that our observations here concern GLT-1.

The relatively small (10-15 pA) inward current mediated by the glutamate transporters depolarizes the membrane potential enough to activate $\mathrm{Ca}^{2+}$ channels in pinealocytes (Figs. 4, 5). The specific electrophysiological properties of pinealocytes are well suited for this scenario: The resting membrane potential of dissociated pinealocytes is not very negative and variously estimated at $-43 \mathrm{mV}$ (Letz et al., 1997), $-31 \mathrm{mV}$ (Aguayo and Weight, 1988), and $-45.4 \mathrm{mV}$ (our measurement). The input resistance of pinealocytes around the resting membrane potential is high
[>1 G $\Omega$ (Aguayo and Weight, 1988); 1-2 G $\Omega(n=3)$ (J. Myung and D.-S. Koh, unpublished observation)]. The L-type $\mathrm{Ca}^{2+}$ channels expressed in pinealocytes begin to open at $-30 \mathrm{mV}$ when measured with $20 \mathrm{~mm} \mathrm{Ba}^{2+}$ (Aguayo and Weight, 1988; Chik et al., 1995). Considering that screening effect by high $\mathrm{Ba}^{2+}$ induces a right shift of the activation curve of voltage-gated channels ( $\sim 15 \mathrm{mV}$ with $20 \mathrm{~mm} \mathrm{Ba}^{2+}$ ) (Hille et al., 1975), the channels are expected to be active even at $-40 \mathrm{mV}$ at the normal $2 \mathrm{~mm}$ $\mathrm{Ca}^{2+}$, just $10 \mathrm{mV}$ above the resting potential. Therefore, transporter-mediated peak and S-S currents in the picoampere range can depolarize the membrane and open $\mathrm{Ca}^{2+}$ channels. Positive to $-20 \mathrm{mV}$, voltage-gated delayed rectifier $\mathrm{K}^{+}$channels activate, preventing additional depolarization (Aguayo and Weight, 1988). The modulation of membrane potential by pineal glutamate transporters appears to operate in this narrow range to support glutamate secretion.

The effect of glutamate transporters on the membrane potential depends on the subtype of the transporter. For example in the EAAT4- and EAAT5-type transporters, the nonstoichiometric $\mathrm{Cl}^{-}$current can be high enough to counteract the inward stoichiometric transporter current. With this kind of transporter, the outward $\mathrm{Cl}^{-}$currents can hyperpolarize the cell, possibly facilitating EAA transport (Eliasof and Jahr, 1996; Dudel and Schramm, 2003). However, in the GLT-1-, GLAST- and EAAC1type glutamate transporters the $\mathrm{Cl}^{-}$conductance is lower and the glutamate transport rates higher (Grewer and Rauen, 2005). Expressing GLT-1 allows pinealocytes to be depolarized on EAA stimulation (Fig. 4).

Depolarization of the membrane by glutamate transporters leads to $\left[\mathrm{Ca}^{2+}\right]_{\mathrm{i}}$ rises (Fig. 5). A significant rise occurs with $10 \mu \mathrm{M}$ $\mathrm{L}$-aspartate, and larger rises occur at higher substrate concentrations. Perhaps both the S-S transporter currents (well activated by $10 \mu \mathrm{M}$ substrate) and the peak currents contribute to the underlying depolarization. Because there is no evidence in the pineal gland for release of EAAs into very confined spaces, their concentration probably never rises to the millimolar range that 


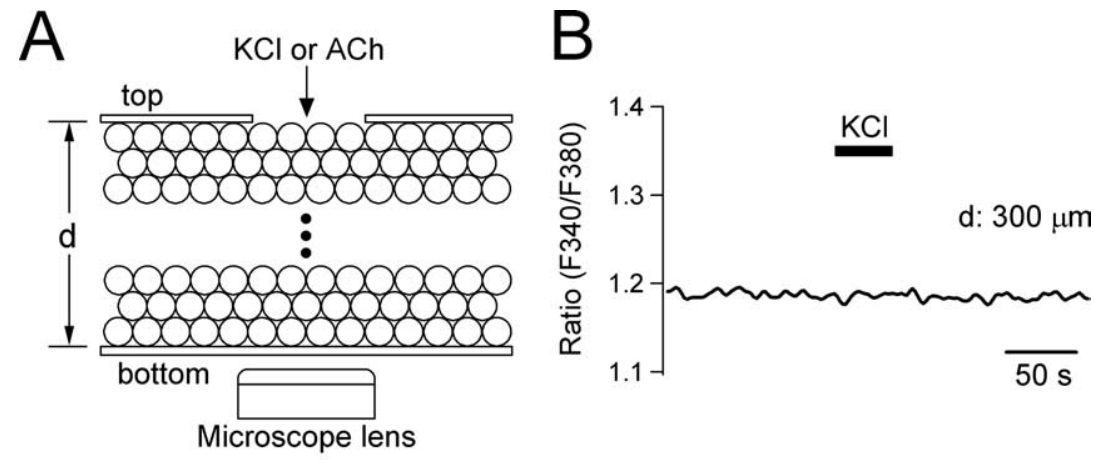

C

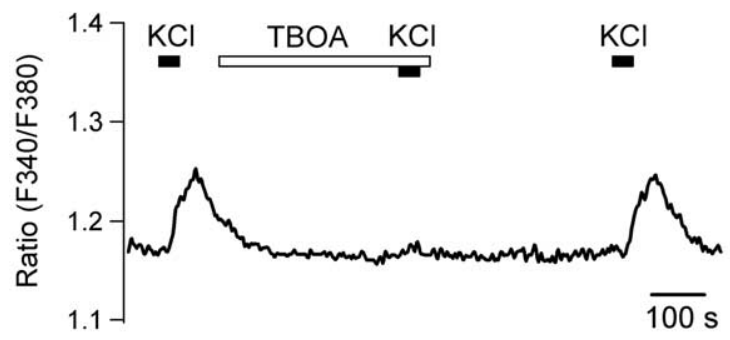

$\mathrm{D}$

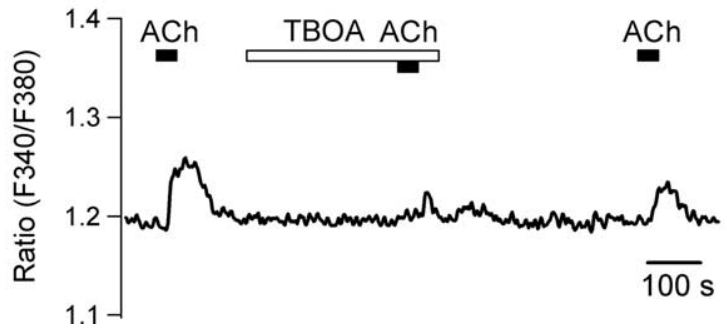

Figure 9. Propagation of $\left[\mathrm{Ca}^{2+}\right]_{i}$ signals via glutamate transporters in pineal slices. $A$, Schematic drawing of experimental setup. A solution containing $50 \mathrm{~mm} \mathrm{KCl}$ was applied to cells on the top side of a pineal slice. $\left[\mathrm{Ca}^{2+}\right]_{\mathrm{i}}$ response was monitored on the cells at bottom of the slice. See supplemental Figure 5 (available at www.jneurosci.org as supplemental material) for the detailed design of the chamber. " $\mathrm{d}$ " denotes the thickness of pineal slices. $B, \mathrm{Ca}^{2+}$ signal measured in the bottom cells of a thick slice (300 $\mu \mathrm{m}$ ) on application of $50 \mathrm{~mm} \mathrm{KCl}$ to the upper surface of the slice. $C$, The $\mathrm{KCl}$ stimulation evoked $\mathrm{Ca}^{2+}$ response at bottom of a thinner slice $(150 \mu \mathrm{m})$. Preincubation of the slice with $600 \mu \mathrm{m}$ TBOA reversibly abolished the $\mathrm{Ca}^{2+}$ signal. Shown is a representative record from eight similar experiments. D, Same experiment performed with a thin slice $(140 \mu \mathrm{m})$ and $200 \mu \mathrm{m}$ ACh. Shown is a single record from 11 similar experiments.

might be seen in some synapses. Nevertheless, the sensitivity to EAAs is sufficient for $\mathrm{Ca}^{2+}$-dependent exocytotic responses.

\section{Glutamate transporter-mediated EAA release}

With amperometry and HPLC, we found that the glutamate transporter evoked $\mathrm{Ca}^{2+}$ influx, exocytosis, and glutamate secretion in the pineal gland (Figs. 6, 7). A few previous studies have raised the possibility of secretion induced by glutamate transporters including reports of the following: (1) increase in intracellular $\mathrm{Ca}^{2+}$ via a high-affinity glutamate transporter in $\mathrm{GH}_{3}$ pituitary cells (secretion of thyroid stimulating hormone was not tested) (Villalobos and Garcia-Sancho, 1995); (2) a depolarization mediated by electrogenic transporters in hippocampal slices (Frenguelli et al., 1991); and (3) transporter-evoked depolarization and $\mathrm{Ca}^{2+}$-dependent glutamate release from cerebral cortical synaptosomes (McMahon et al., 1989).

The glutamate transporter of the pineal gland triggers exocytosis of its own substrates, EAAs stored in SLMVs. Such stimulussecretion coupling suggests that transporters might not clear extracellular EAAs efficiently. What would be the physiological significance of glutamate-evoked glutamate release? Pineal glands are compactly packed with pinealocytes ( $\sim 90 \%$ in rat) $\mathrm{d}: 140 \mu \mathrm{m}$

together with some minor cell types such as interstitial glial cells (Pévet, 1983). With this structural organization, perhaps EAAs released into the interstitial space from a pinealocyte could recruit the release of EAAs from neighboring cells. Whether this regenerative paracrine mechanism exists and, if so, how far the glutamate signal propagates should depend on several factors. They include the amount of EAA secreted from a stimulated cell (efficiency of the stimulus-secretion coupling), the volume of the interstitial space (determining the dilution of secreted EAAs), and the type of EAAT expressed (determining net inward vs net outward transporter current). Our results using pineal slices suggest that spreading or propagation of the EAA signals is possible (Figs. 8,9 ).

\section{Potential role of EAA signals}

The pineal gland secretes melatonin with a well defined daily rhythm (Ganguly et al., 2002). The synthesis of melatonin is under a variety of neural and hormonal controls (Simonneaux and Ribelayga, 2003). The best understood is the sympathetic input from the superior cervical ganglion, which, in turn, is driven by suprachiasmatic nucleus, the master circadian clock (Ganguly et al., 2002). At night, norepinephrine released from the sympathetic terminals activates serotonin- $N$ acetyltransferase (NAT), the rate-limiting enzyme in melatonin production, mainly by acting through $\beta_{1}$-adrenergic receptors to increase cAMP.

The pineal is also innervated by parasympathetic cholinergic inputs from peripheral ganglia and the CNS (Phansuwan-Pujito et al., 1999). Acetylcholine evokes release of L-glutamate and L-aspartate by activating nicotinic acetylcholine receptors present on pinealocytes (Letz et al., 1997; Yamada et al., 1998b). The nicotinic receptor induces membrane depolarization, $\mathrm{Ca}^{2+}$ rise through L-type voltage-gated $\mathrm{Ca}^{2+}$ channel, and $\mathrm{Ca}^{2+}$-evoked exocytosis of SLMV, much as glutamate transporters do. From these considerations, it is tempting to suggest that EAAs are initially released from pinealocytes innervated by cholinergic nerve terminals (Yamada et al., 1998b), and the EAAs in turn activate neighboring cells via glutamate transporters and evoke additional release of EAA (Yamada et al., 1996b). Then regenerative spread of EAA signals in the pineal gland can reduce melatonin synthesis by activating class II metabotropic glutamate receptors (mGluRs), in turn reducing the activity of the serotonin- $N$-acetyltransferase (Kus et al., 1994; Yamada et al., 1998a). Indeed, we have shown previously that exogenous acetylcholine inhibits melatonin synthesis in a manner involving glutamate release and mGluR activation (Yamada et al., 1998b). In summary, cholinergic input, when coupled to this putative paracrine mechanism using EAAs, could effectively inhibit melatonin synthesis and counteract the stimulatory norepinephrine system as originally suggested by Phansuwan-Pujito et al. (1999). At night, when it is desirable to 


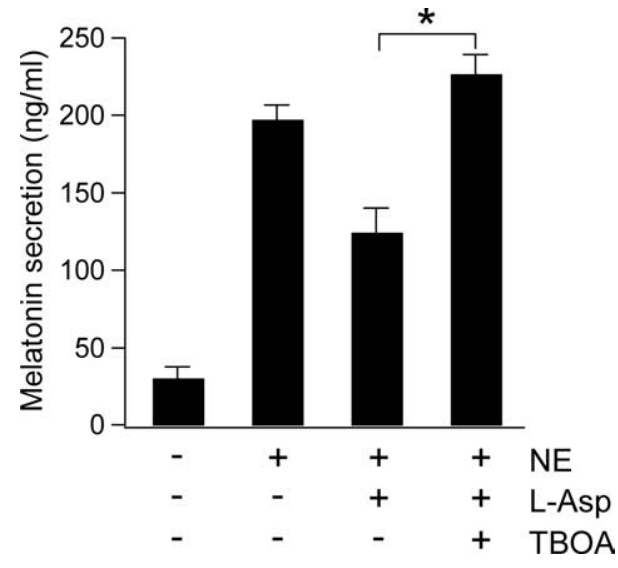

Figure 10. Effect of glutamate transporters on NE-evoked melatonin secretion. Pineal glands were treated with a combination of $10 \mu \mathrm{m} \mathrm{NE}, 500 \mu \mathrm{M} \mathrm{L}$-aspartate, and $300 \mu \mathrm{m}$ TBOA for $6 \mathrm{~h}$ at physiological $37^{\circ} \mathrm{C}$, and released melatonin was measured (four independent experiments for each condition). Error bars indicate SEM. * $p<0.01$.

maintain low levels of glutamate in the pineal, the transporters probably take on their usual role of clearing background glutamate and generate insufficient depolarization to stimulate regenerative release. This would avoid unnecessary activation of inhibitory mGluRs that has a high affinity to glutamate (Pin and Duvoisin, 1995).

In the pineal, D-aspartate is highly accumulated (Lee et al., 1997; Schell et al., 1997) and has been implicated in control of melatonin secretion (Ishio et al., 1998; Takigawa et al., 1998). D-Aspartate, partly synthesized in other tissues, is taken up into pinealocytes by the glutamate transporter and distributed in the cytoplasm but not into SLMVs. The cytosolic D-aspartate is known to be released significantly by norepinephrine. Previously, we and others have shown that D-aspartate inhibited the norepinephrine-evoked serotonin- $N$-acetyltransferase activity and melatonin synthesis by a novel mechanism (Ishio et al., 1998; Takigawa et al., 1998): A hypothetical glutamate receptor responding to D-aspartate was suggested to explain the result. However, based on our present results, the released D-aspartate evokes L-glutamate secretion mediated by the glutamate transporters, and this L-glutamate inhibits serotonin- $N$-acetyltransferase via an inhibitory mGluR. In this case, the glutamate transportermediated glutamate secretion forms a central part of the negative feedback for sympathetic input. In line with this idea, all substrates of pineal glutamate transporters decreased melatonin synthesis induced by NE, whereas D-glutamate had no effect (Kus et al., 1994; Yamada et al., 1997a, 1998a; Ishio et al., 1998). Our preliminary experiment (Fig. 10) does suggest that the inhibition of melatonin secretion was mediated by the activation of glutamate transporters.

Together, our work presents the first clear evidence that glutamate transporters can trigger vesicular exocytosis of neurotransmitters and suggests a novel function of glutamate transporter-mediated EAA release in the pineal gland.

\section{References}

Aguayo LG, Weight FF (1988) Characterization of membrane currents in dissociated adult rat pineal cells. J Physiol 405:397-419.

Arriza JL, Fairman WA, Wadiche JI, Murdoch GH, Kavanaugh MP, Amara SG (1994) Functional comparisons of three glutamate transporter subtypes cloned from human motor cortex. J Neurosci 14:5559-5569.

Arriza JL, Eliasof S, Kavanaugh MP, Amara SG (1997) Excitatory amino acid transporter 5 , a retinal glutamate transporter coupled to a chloride conductance. Proc Natl Acad Sci U S A 94:4155-4160.
Bergles DE, Jahr CE (1997) Synaptic activation of glutamate transporters in hippocampal astrocytes. Neuron 19:1297-1308.

Bergles DE, Tzingounis AV, Jahr CE (2002) Comparison of coupled and uncoupled currents during glutamate uptake by GLT-1 transporters. J Neurosci 22:10153-10162.

Brew H, Attwell D (1987) Electrogenic glutamate uptake is a major current carrier in the membrane of axolotl retinal glial cells. Nature 327:707-709.

Castellano A, López-Barneo J, Armstrong CM (1989) Potassium currents in dissociated cells of the rat pineal gland. Pflugers Arch 413:644-650.

Chik CL, Liu QY, Li B, Karpinski E, Ho AK (1995) cGMP inhibits L-type $\mathrm{Ca}^{2+}$ channel currents through protein phosphorylation in rat pinealocytes. J Neurosci 15:3104-3109.

Danbolt NC (2001) Glutamate uptake. Prog Neurobiol 65:1-105.

Dingledine R, Borges K, Bowie D, Traynelis SF (1999) The glutamate receptor ion channels. Pharmacol Rev 51:7-61.

Dudel J, Schramm M (2003) A receptor for presynaptic glutamatergic autoinhibition is a glutamate transporter. Eur J Neurosci 18:902-910.

Dudel J, Franke C, Hatt H (1990) Rapid activation, desensitization, and resensitization of synaptic channels of crayfish muscle after glutamate pulses. Biophys J 57:533-545.

Eliasof S, Jahr CE (1996) Retinal glial cell glutamate transporter is coupled to an anionic conductance. Proc Natl Acad Sci U S A 93:4153-4158.

Eliasof S, Werblin F (1993) Characterization of the glutamate transporter in retinal cones of the tiger salamander. J Neurosci 13:402-411.

Fairman WA, Vandenberg RJ, Arriza JL, Kavanaugh MP, Amara SG (1995) An excitatory amino-acid transporter with properties of a ligand-gated chloride channel. Nature 375:599-603.

Frenguelli BG, Blake JF, Brown MW, Collingridge GL (1991) Electrogenic uptake contributes a major component of the depolarizing action of L-glutamate in rat hippocampal slices. Br J Pharmacol 102:355-362.

Ganguly S, Coon SL, Klein DC (2002) Control of melatonin synthesis in the mammalian pineal gland: the critical role of serotonin acetylation. Cell Tissue Res 309:127-137.

Grewer C, Rauen T (2005) Electrogenic glutamate transporters in the CNS: molecular mechanism, pre-steady-state kinetics, and their impact on synaptic signaling. J Membr Biol 203:1-20.

Grewer C, Watzke N, Wiessner M, Rauen T (2000) Glutamate translocation of the neuronal glutamate transporter EAAC1 occurs within milliseconds. Proc Natl Acad Sci U S A 97:9706-9711.

Grynkiewicz G, Poenie M, Tsien RY (1985) A new generation of $\mathrm{Ca}^{2+}$ indicators with greatly improved fluorescence properties. J Biol Chem 260:3440-3450.

Herrington J, Park YB, Babcock DF, Hille B (1996) Dominant role of mitochondria in clearance of large $\mathrm{Ca}^{2+}$ loads from rat adrenal chromaffin cells. Neuron 16:219-228.

Hille B, Woodhull AM, Shapiro BI (1975) Negative surface charge near sodium channels of nerve: divalent ions, monovalent ions, and $\mathrm{pH}$. Philos Trans R Soc Lond B Biol Sci 270:301-318.

Horn R, Marty A (1988) Muscarinic activation of ionic currents measured by a new whole-cell recording method. J Gen Physiol 92:145-159.

Ishio S, Yamada H, Hayashi M, Yatsushiro S, Noumi T, Yamaguchi A, Moriyama Y (1998) D-Aspartate modulates melatonin synthesis in rat pinealocytes. Neurosci Lett 249:143-146.

Kanai Y, Hediger MA (1992) Primary structure and functional characterization of a high-affinity glutamate transporter. Nature 360:467-471.

Kim KT, Koh DS, Hille B (2000) Loading of oxidizable transmitters into secretory vesicles permits carbon-fiber amperometry. J Neurosci 20:RC101(1-5).

Koh DS, Hille B (1997) Modulation by neurotransmitters of catecholamine secretion from sympathetic ganglion neurons detected by amperometry. Proc Natl Acad Sci U S A 94:1506-1511.

Koh DS, Hille B (1999) Rapid fabrication of plastic-insulated carbon-fiber electrodes for micro-amperometry. J Neurosci Methods 88:83-91.

Koh DS, Burnashev N, Jonas P (1995) Block of native $\mathrm{Ca}^{2+}$-permeable AMPA receptors in rat brain by intracellular polyamines generates double rectification. J Physiol 486:305-312.

Kus L, Handa RJ, McNulty JA (1994) Glutamate inhibition of the adrenergic-stimulated production of melatonin in rat pineal gland in vitro. J Neurochem 62:2241-2245.

Lee JA, Homma H, Sakai K, Fukushima T, Santa T, Tashiro K, Iwatsubo T, Yoshikawa M, Imai K (1997) Immunohistochemical localization of 
D-aspartate in the rat pineal gland. Biochem Biophys Res Commun 231:505-508.

Letz B, Schomerus C, Maronde E, Korf HW, Korbmacher C (1997) Stimulation of a nicotinic $\mathrm{ACh}$ receptor causes depolarization and activation of L-type $\mathrm{Ca}^{2+}$ channels in rat pinealocytes. J Physiol 499:329-340.

Levy LM, Warr O, Attwell D (1998) Stoichiometry of the glial glutamate transporter GLT-1 expressed inducibly in a Chinese hamster ovary cell line selected for low endogenous $\mathrm{Na}^{+}$-dependent glutamate uptake. J Neurosci 18:9620-9628.

McBain CJ, Mayer ML (1994) N-Methyl-D-aspartic acid receptor structure and function. Physiol Rev 74:723-760.

McMahon HT, Barrie AP, Lowe M, Nicholls DG (1989) Glutamate release from guinea-pig synaptosomes: stimulation by reuptake-induced depolarization. J Neurochem 53:71-79.

Otis TS, Kavanaugh MP (2000) Isolation of current components and partial reaction cycles in the glial glutamate transporter EAAT2. J Neurosci 20:2749-2757.

Owe SG, Marcaggi P, Attwell D (2006) The ionic stoichiometry of the GLAST glutamate transporter in salamander retinal glia. J Physiol 577:591-599.

Pévet P (1983) Anatomy of the pineal gland of mammals. In: The pineal gland (Relkin R, ed), pp 1-75. New York: Elsevier Science.

Phansuwan-Pujito P, Møller M, Govitrapong P (1999) Cholinergic innervation and function in the mammalian pineal gland. Microsc Res Tech 46:281-295.

Pin JP, Duvoisin R (1995) The metabotropic glutamate receptors: structure and functions. Neuropharmacology 34:1-26.

Pines G, Danbolt NC, Bjørås M, Zhang Y, Bendahan A, Eide L, Koepsell H, Storm-Mathisen J, Seeberg E, Kanner BI (1992) Cloning and expression of a rat brain L-glutamate transporter. Nature 360:464-467.

Rothstein JD, Dykes-Hoberg M, Pardo CA, Bristol LA, Jin L, Kuncl RW, Kanai Y, Hediger MA, Wang Y, Schielke JP, Welty DF (1996) Knockout of glutamate transporters reveals a major role for astroglial transport in excitotoxicity and clearance of glutamate. Neuron 16:675-686.

Schell MJ, Cooper OB, Snyder SH (1997) D-Aspartate localizations imply neuronal and neuroendocrine roles. Proc Natl Acad Sci USA 94:2013-2018.

Shimamoto K, Lebrun B, Yasuda-Kamatani Y, Sakaitani M, Shigeri Y, Yumoto N, Nakajima T (1998) DL-threo- $\beta$-Benzyloxyaspartate, a potent blocker of excitatory amino acid transporters. Mol Pharmacol 53:195-201.

Simonneaux V, Ribelayga C (2003) Generation of the melatonin endocrine message in mammals: a review of the complex regulation of melatonin synthesis by norepinephrine, peptides, and other pineal transmitters. Pharmacol Rev 55:325-395.

Storck T, Schulte S, Hofmann K, Stoffel W (1992) Structure, expression, and functional analysis of a $\mathrm{Na}^{+}$-dependent glutamate/aspartate transporter from rat brain. Proc Natl Acad Sci U S A 89:10955-10959.

Takahashi T (1978) Intracellular recording from visually identified motoneurons in rat spinal cord slices. Proc R Soc Lond B Biol Sci 202:417-421.

Takigawa Y, Homma H, Lee JA, Fukushima T, Santa T, Iwatsubo T, Imai K (1998) D-Aspartate uptake into cultured rat pinealocytes and the concomitant effect on L-aspartate levels and melatonin secretion. Biochem Biophys Res Commun 248:641-647.

Tzingounis AV, Wadiche JI (2007) Glutamate transporters: confining run- away excitation by shaping synaptic transmission. Nat Rev Neurosci 8:935-947.

Villalobos C, García-Sancho J (1995) Glutamate increases cytosolic calcium in GH3 pituitary cells acting via a high-affinity glutamate transporter. FASEB J 9:815-819.

Wadiche JI, Kavanaugh MP (1998) Macroscopic and microscopic properties of a cloned glutamate transporter/chloride channel. J Neurosci 18:7650-7661.

Wadiche JI, Arriza JL, Amara SG, Kavanaugh MP (1995a) Kinetics of a human glutamate transporter. Neuron 14:1019-1027.

Wadiche JI, Amara SG, Kavanaugh MP (1995b) Ion fluxes associated with excitatory amino acid transport. Neuron 15:721-728.

Wadiche JI, Tzingounis AV, Jahr CE (2006) Intrinsic kinetics determine the time course of neuronal synaptic transporter currents. Proc Natl Acad Sci U S A 103:1083-1087.

Weiss JH, Hartley DM, Koh J, Choi DW (1990) The calcium channel blocker nifedipine attenuates slow excitatory amino acid neurotoxicity. Science 247:1474-1477.

Yamada H, Yamamoto A, Takahashi M, Michibata H, Kumon H, Moriyama $\mathrm{Y}$ (1996a) The L-type $\mathrm{Ca}^{2+}$ channel is involved in microvesiclemediated glutamate exocytosis from rat pinealocytes. J Pineal Res 21:165-174.

Yamada H, Yamamoto A, Yodozawa S, Kozaki S, Takahashi M, Morita M, Michibata H, Furuichi T, Mikoshiba K, Moriyama Y (1996b) Microvesicle-mediated exocytosis of glutamate is a novel paracrine-like chemical transduction mechanism and inhibits melatonin secretion in rat pinealocytes. J Pineal Res 21:175-191.

Yamada H, Yamaguchi A, Moriyama Y (1997a) L-Aspartate-evoked inhibition of melatonin production in rat pineal glands. Neurosci Lett 228:103-106.

Yamada H, Yatsushiro S, Yamamoto A, Hayashi M, Nishi T, Futai M, Yamaguchi A, Moriyama Y (1997b) Functional expression of GLT-1 type $\mathrm{Na}^{+}$-dependent glutamate transporter in rat pinealocytes. J Neurochem 69:1491-1498.

Yamada H, Yatsushiro S, Ishio S, Hayashi M, Nishi T, Yamamoto A, Futai M, Yamaguchi A, Moriyama Y (1998a) Metabotropic glutamate receptors negatively regulate melatonin synthesis in rat pinealocytes. J Neurosci 18:2056-2062.

Yamada H, Ogura A, Koizumi S, Yamaguchi A, Moriyama Y (1998b) Acetylcholine triggers L-glutamate exocytosis via nicotinic receptors and inhibits melatonin synthesis in rat pinealocytes. J Neurosci 18:4946-4952.

Yamada H, Hayashi M, Uehara S, Kinoshita M, Muroyama A, Watanabe M, Takei K, Moriyama Y (2002) Norepinephrine triggers $\mathrm{Ca}^{2+}$-dependent exocytosis of 5-hydroxytryptamine from rat pinealocytes in culture. J Neurochem 81:533-540.

Yatsushiro S, Yamada H, Kozaki S, Kumon H, Michibata H, Yamamoto A, Moriyama Y (1997) L-Aspartate but not D form is secreted through microvesicle-mediated exocytosis and is sequestered through $\mathrm{Na}^{+}-$ dependent transporter in rat pinealocytes. J Neurochem 69:340-347.

Yatsushiro S, Yamada H, Hayashi M, Yamamoto A, Moriyama Y (2000) Ionotropic glutamate receptors trigger microvesicle-mediated exocytosis of L-glutamate in rat pinealocytes. J Neurochem 75:288-297.

Yuste R (2000) Loading brain slices with AM esters of calcium indicators. In: Imaging neurons: a laboratory manual (Yuste R, Lanni F, Konnerth A, eds), pp 34.1-34.9. New York: Cold Spring Harbor Laboratory.

Zerangue N, Kavanaugh MP (1996) Flux coupling in a neuronal glutamate transporter. Nature 383:634-637. 